\title{
Synthetic and application of a novel resin from waste foam packing for adsorption of Acid Orange 67 from aqueous solution
}

\author{
Nora Mohamed Hilal (D, Nagwa Abdelfattah Badawy, Omaima Ibrahim Mostafa and Heba Mohamed Elrefay
}

\begin{abstract}
Background: The type of dyes used in textile industries are synthetic dyes which are toxic and cause harm to the aquatic ecosystem; in this paper, adsorptive removal of dye Color Index Acid Orange 67 pollutant from aqueous solutions using a novel resin synthetic from waste foam packing was investigated using the batch method.

Results: The adsorbent was characterized by Fourier-transform infrared spectroscopy (FTIR), surface morphology, and zero surface charge. Batch adsorption studies were carried out under various parameters such as contact time, $\mathrm{pH}$, initial dye concentration, adsorbent dosage, and solution temperature on the removal of AO67. Experimental isotherm data were analyzed using Langmuir, Freundlich, Dubinin-Radushkevich (D-R), and Temkin isotherm models, and the isotherm constants were calculated using linear regression analysis for the determination of the isotherm parameters which describe the adsorption process. The best fit was obtained by Langmuir model. A comparison of kinetic models applied to the adsorption of Acid Orange 67 (AO67) onto resin polystyrene foam (RPSF) was evaluated for the pseudofirst-order, the pseudo-second-order, Elovich, intraparticle diffusion, and Bangham's kinetics models. The adsorption kinetic data were properly fitted very well with the pseudo-second-order kinetic model. The thermodynamic parameters and activation energy were evaluated.
\end{abstract}

Conclusion: The results have established good potentiality for the RPSF to be used as an adsorbent for the removal of AO67 from aqueous solutions. The optimum conditions attained in this study were used for removal of (RB222, RY145, and AR37) from the simulated wastewaters onto RPSF.

Keywords: Textile waste, Adsorption, Synthetic resin, Thermodynamics, Kinetics and isotherm

\section{Background}

Dyes are the major pollutants of the wastewater produced by industries such as textile, paint, and cosmetics (Adak et al. 2005; Hameed and Ahmad 2009; Bhattacharyya and Sharma 2005 and $\mathrm{Hu}$ 2007). The productions of dyes are over $7 \times 10^{5}$ metric tons based on worldwide research, and $5-10 \%$ of the dyes are lost in industrial effluents (Bajpai and Sorptive 2010). Since textile industries consume large quantities of water, the wastewater produced large volume of dyes (Hameed and Ahmad 2009). Moreover, the type of dyes used in textile industries are synthetic dyes which are toxic dyes and cause harm to the aquatic ecosystem (Adak et al. 2005

\footnotetext{
* Correspondence: norahelal832@yahoo.com

Chemistry Department, Faculty of Science, Al-Azhar University (Girls), PO box 11754,Yousef Abas Str., Naser City, Cairo, Egypt
}

and Bajpai and Sorptive 2010). Other than that, dyes consist of carcinogenic and mutagenic effects which can affect aquatic life and human (Bhattacharyya and Sharma 2005). To avoid this kind of disease, researchers have found some method to remove dyes from wastewater. There are a few methods used in dye removal such as sedimentation, chemical treatment, oxidation, biological treatment, electrochemical methodology, and finally adsorption (Gupta 2009). Adsorption is widely used because this method requires simple operation procedures, low cost compared to the other separation process and no sludge formation (Mohanty 2006). The adsorption method will use an adsorbent as a medium to adsorb dyes from the wastewater. There are several types of adsorbents: alumina, iron oxide, zeolites, activated carbon, and natural adsorbents (Gupta 2009). Natural adsorbents are widely used because these 
materials are low cost and waste materials. The natural adsorbents usually used as adsorbent for dye removal are peat, chitosan, natural coal, cotton, orange peel, etc. (Gupta 2009). Polystyrene is most commonly used now, thermoplastic substances that are solid state in room temperature, are not biodegradable, and resist photolysis. The foam polystyrene products are ubiquitously used as insulation and used in industrial applications such as foam packaging for food, air bubble plastics, and foam drink cups (Prapat et al. 2011).

Polystyrene is an aromatic polymer that is made from the monomer styrene. It is along hydrocarbon chain that has a phenyl group attached to every carbon atom. Polystyrene foam are considered as plastic waste foams, interesting and alternative synthetic adsorbent materials, and used as new sorbents for adsorption of pollutant dyes as acid orange 67 (AO67) dye for waste water treatment. The synthetic resin from waste foam packing is an excellent sorbent material due to its highly available surface area and extremely low cost. In addition, it is stable in acids and bases. The capacity of waste polystyrene plastics for dye removal was investigated in this study.

\section{Materials and methods}

\section{Materials}

All chemicals used in this study were of analytical grade. Sulfuric acid, sodium hydroxide, and sodium chloride were supplied from Aldrich Company, and Acid dye, nylomine orange (C.I. Acid Orange 67) was supplied Imperial Chemical Industries, ICI. The absorption maximum was observed for acid orange 67 dye at $442 \mathrm{~nm}$ in pure aqueous solution, and the chemical structure of AO67 show in Scheme 1. The wastes of polystyrene foam for food packaging (Scheme 2) were collected from the environment. All chemicals were used without further purifications. Double distilled water was used throughout the experiments for preparation and dilution of the solutions.

\section{Preparation of resin from waste foam packing}

The synthetic resins were prepared from wastes polystyrene foam for food packaging. The method for resin preparation was applied based briefly from Bekri-Abbes

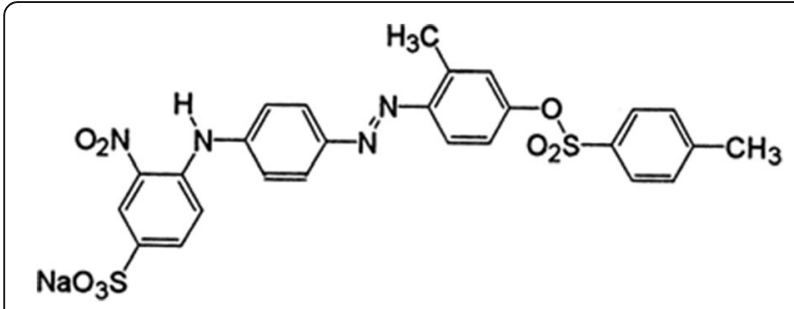

Scheme 1 Chemical structure of C.I. Acid Orange 67(AO67) dye et al. 2008, polystyrene foam was crushed to obtain a size of $0.2-0.3 \mathrm{~cm}^{2}$ for the total weight of about $30 \mathrm{~g}$. Each $5 \mathrm{~g}$ of raw material was transferred in a flask with $100 \mathrm{~mL} 95 \%$ sulfuric acid and left to react under room temperature till the reaction period is completed. The slurry was filtered with a funnel and washed with $250 \mathrm{~mL}$ of distilled water for ten times. The $\mathrm{pH}$ paper was using to check the residual sulfuric acid in washed water to ensure the removal from resin. The resin was then dried at $40^{\circ} \mathrm{C}$ for $30 \mathrm{~min}$. The neutralization process was introduced by stirring the resin for $2 \mathrm{~h}$ at $500 \mathrm{ml} 1 \mathrm{M} \mathrm{NaCl}$ solution. This process aims to convert the sulfonated polymer resin into its $\mathrm{Na}^{+}$form. The ion exchange capacity was evaluated by measuring the concentration of $\mathrm{H}^{+}$ which was exchange with $\mathrm{Na}^{+}$when the acid form of sulfonated polystyrene was equilibrated with $\mathrm{NaCl}$ solution. The dry polymer $(5 \mathrm{~g})$ in the $\mathrm{H}^{+}$form was placed in $100 \mathrm{~mL}$ of $0.2 \mathrm{M} \mathrm{NaCl}$ solution and shaken for $2 \mathrm{~h}$, and the amount of $\mathrm{H}^{+}$released by the polymer was determined by titration with $0.01 \mathrm{M} \mathrm{NaOH}$. The finished synthetic resin from waste polystyrene foam packaging (RPSF) is shown in Fig. 1.

\section{Apparatus of surface characterization}

The surface morphology of the synthetic resin from waste polystyrene foam packaging (RPSF) was characterized by using scanning electron microscope (SEM; JEOL JSM-5400 SEM, Tokyo, Japan) and was operated at 20 $\mathrm{kV}$. In order to increase the conductivity of the samples, they were gold coated using a JEOL FRC 1200 fine coater before taking SEM. The powder X-ray diffraction patterns were obtained on a Pan analytical X-ray diffractometer (PW1830). Transmission electron microscope (TEM) measurements were performed using JEOL JEM-1010 (Tokyo, Japan) with resolution point $0.45 \mathrm{~nm}$ to characterize the synthetic resin (RPSF), operated at $200 \mathrm{kV}$. The synthetic resin (RPSF) was dispersed in ethanol, and then a drop of the above dispersion was taken on a carbon coated copper grid (300 meshes) for TEM imaging. Fourier-transform infrared (FTIR) spectroscopy was used in order to analyze and detect the functional group which presented in samples before and after adsorption process. FTIR spectra were recorded on Mattson 1000, Unicam infrared spectrophotometer, Cambridge, England, in the range $400-4000 \mathrm{~cm}^{-1}$ using $\mathrm{KBr}$ pellets. A dry constant weight from RPSF was ground with $20 \mathrm{mg}$ of $\mathrm{KBr}$ and then pressed to form transparent disks. The zero-point charge of synthetic resin (RPSF) was determined by a digital $\mathrm{pH}$ meter (Satorius Model PB-11) combined with glass electrode and was used for other all experiments. A UV-spectrophotometer (Model T60 spectrophotometer, UK) was 


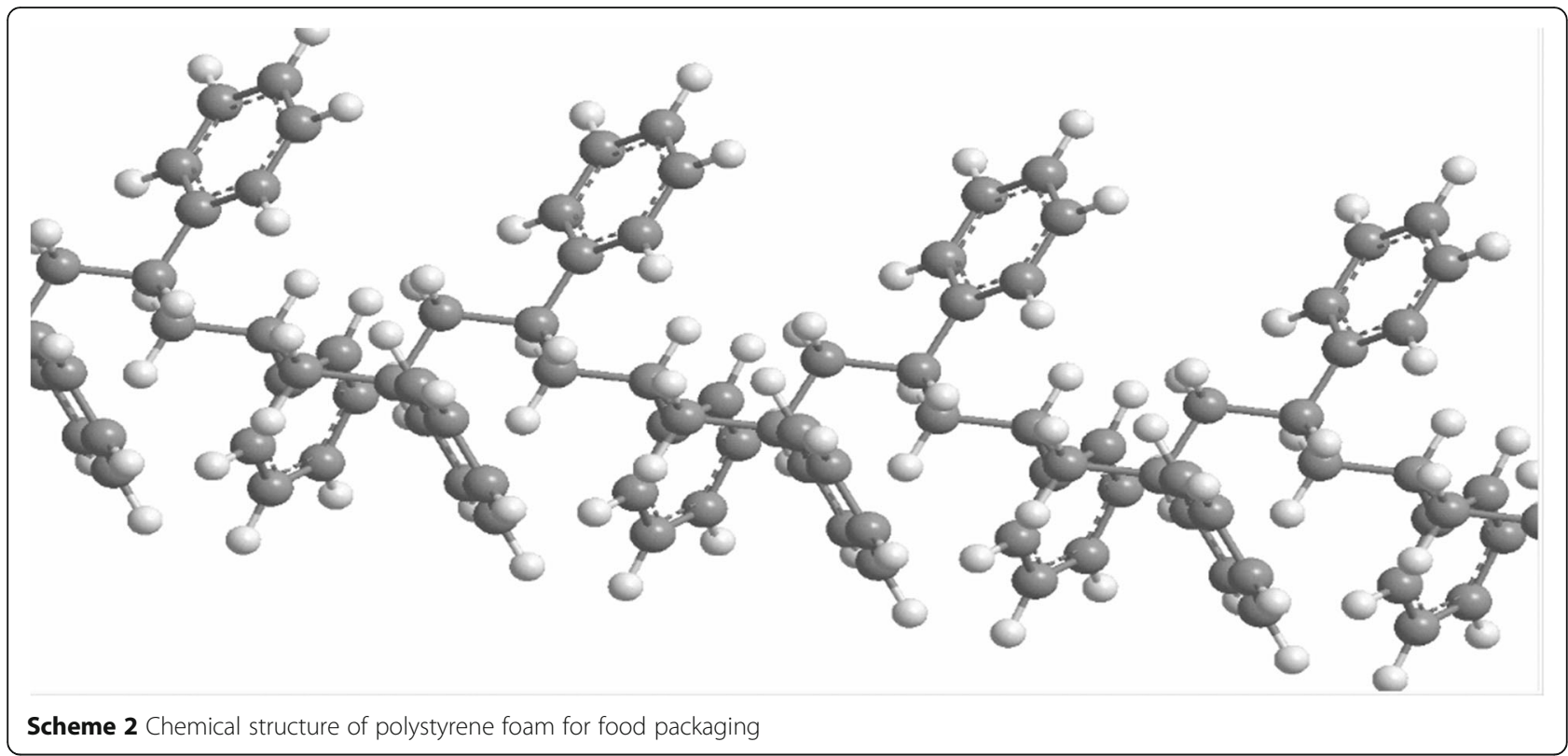

used for adsorption study of Color Index (C.I.) Acid Orange 67.

The surface areas of the synthetic resin (RPSF) were measured using Sears method (Sears 1956). A sample containing $0.5 \mathrm{~g}$ of each adsorbent was acidified with 0.1 $\mathrm{N} \mathrm{HCl}$ to $\mathrm{pH} 3$ to 3.5. The volume was made up to 50 $\mathrm{ml}$ with distilled water after addition of $10.0 \mathrm{~g}$ of $\mathrm{NaCl}$. The titration was carried out with standard $0.1 \mathrm{M} \mathrm{NaOH}$ in a thermostatic bath at $30^{\circ} \mathrm{C}$ to $\mathrm{pH} 4.0$ and then to $\mathrm{pH}$ 9.0. The volume, $\mathrm{V}$, required to raise the $\mathrm{pH}$ from 4.0 to 9.0 was noted, and the surface area $\left(\mathrm{S} ; \mathrm{m}^{2} \mathrm{~g}^{1}\right)$ was computed from the Eq. (1).

$$
S=32 \mathrm{~V}-25
$$

\section{Batch adsorption studies}

The effect of various parameters on the removal of C.I. Acid Orange 67 onto synthetic resin (RPSF) was studied. For each experimental run, $40 \mathrm{ml}$ of dye solutions of known initial concentration and $\mathrm{pH}$ was taken in 100-ml plugged conical flask. A suitable adsorbent dose of synthetic resin (RPSF) was added to conical flasks containing $40 \mathrm{~mL}$ dye solutions; adsorption of dye solutions was carried out at $25 \pm 1{ }^{\circ} \mathrm{C}$ for $24 \mathrm{~h}$ in batch system, and the
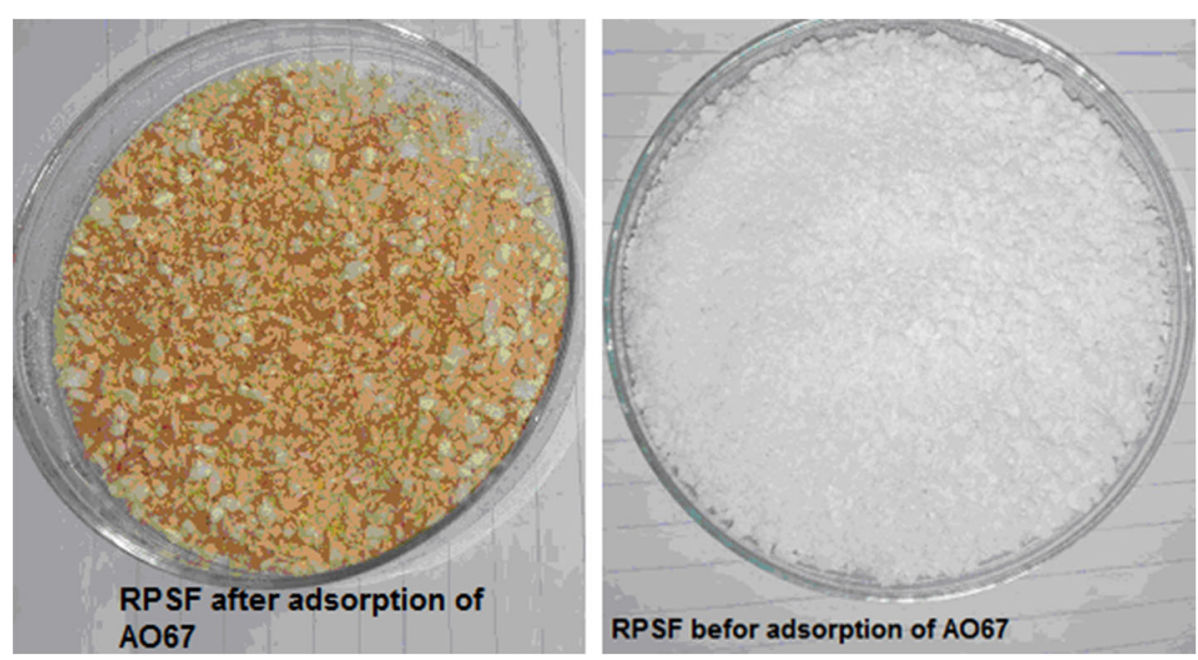

Fig. 1 Showing the Synthetic resins from waste foam (RPSF) 
mixture was shaken at a constant agitation speed (200 $\mathrm{rpm}$ ) for $1 \mathrm{~h}$. After shaking, the suspension was separated from the adsorbent by centrifugation at a rotation speed of $6000 \mathrm{r} / \mathrm{min}$ for $5 \mathrm{~min}$. Adsorption equilibrium isotherms were studied using synthetic resin (RPSF) dosages from $(0.02-0.4 \mathrm{~g})$ per $40 \mathrm{ml}$ of dye solutions. Initial concentrations were ranged from $5-150 \mathrm{mg} / \mathrm{L}$ using initial $\mathrm{pH} 2.5 \pm 0.5$ which is lower than the $\mathrm{pH}_{\mathrm{pzc}}$ of the adsorbent; the solution was separated from the mixture and analyzed for A.O 67 concentration. The amount of dye adsorbed per unit mass of the adsorbent was analyzed by UV-visible spectrophotometer and calculated as follows:

$$
q_{\mathrm{e}}(\mathrm{mg} / \mathrm{g})=\left[C_{\mathrm{o}}-C_{\mathrm{e}}\right] V / M
$$

and the percent removal may be calculated as:

$$
\operatorname{Removal} \%=\left[\left(C_{\mathrm{o}}-C_{\mathrm{e}}\right) / \mathrm{C}_{\mathrm{o}}\right] 100
$$

where $C_{\mathrm{o}}$ is the initial concentration $(\mathrm{mg} / \mathrm{L}), C_{\mathrm{e}}$ is the dye concentration $(\mathrm{mg} / \mathrm{L})$ at any time, $V$ is the volume of the solution (L), and $M$ is the weight of the adsorbent used $(\mathrm{g})$. The effect of $\mathrm{pH}$ on the rate of adsorption was investigated using dye concentration of $100 \mathrm{mg} / \mathrm{L}$ for constant synthetic resin (RPSF) dosages. The $\mathrm{pH}$ values were adjusted with $0.5 \mathrm{~N} \mathrm{HCl}$ and $0.5 \mathrm{~N} \mathrm{NaOH}$ solutions.

The suitability of the Langmuir, Freundlich, DubininRadushkevich (D-R), and Temkin adsorption models to the equilibrium data were investigated for dye sorbent system.

\section{Results}

The surface morphology of synthetic resin (RPSF) obtained from waste environment is characterized by high porosity as shown in Fig. 2a and b. Fine micro particles were observed with a diameter of $200 \mu \mathrm{m}$ in the SEM of synthetic resin (RPSF). The presence of these fine particles leads to an increase in the porosity, and the surface area of the synthetic resin (RPSF) was confirmed by the measured surface area $\left(23 \mathrm{~m}^{2} \mathrm{~g}^{-1}\right)$.

\section{FTIR spectra of synthetic resin prepared from wastes polystyrene foam (RPSF)}

Figure 3 shows the FTIR spectra of raw polystyrene foam and synthetic resin prepared from polystyrene foam, from which changes in the structures of polystyrene foam on sulfonation were deduced. These corresponded with the appearance of new absorption bands and the splitting of others, consistent with the presence of $-\mathrm{SO}_{3} \mathrm{Na}$ group on the aromatic ring. New absorption bands at 1250 and $1078 \mathrm{~cm}^{-1}$ were assigned to the stretching of the asymmetric and symmetric stretching of the $\mathrm{O}=\mathrm{S}=\mathrm{O}$ group, respectively.

\section{Zero surface charges of resin polystyrene foam (RPSF)}

The point zero charge $\left(\mathrm{pH}_{\mathrm{pzc}}\right)$ of RPSF was determined by the solid addition method. The net charge of surface is zero on the adsorbent surface at $\mathrm{pH}_{\mathrm{pzc}}$; therefore, no activation of acidic or basic functional groups are detected on the solution $\mathrm{pH}$. Batch equilibrium method was used for the determination of point of zero charge. To each of the flask, $0.1 \mathrm{~g}$ of respective adsorbents was added including $100 \mathrm{ml}$ solution KNO3 $(0.01 \mathrm{~N})$ in the $\mathrm{pH}$ range between 2 and 10. The initial $\mathrm{pH}$ of solutions was adjusted by adding drops of $0.5 \mathrm{~N} \mathrm{NaOH}$ and $0.5 \mathrm{~N}$ $\mathrm{HCl}$ solutions; each flask was sealed and shaken thoroughly for $48 \mathrm{~h}$ at room temperature, and the final $\mathrm{pH}_{\mathrm{f}}$ of the solution was measured and recorded. The total charge adsorbed on RPSF surface was determined by $\Delta \mathrm{pH}$ (the difference in the value of $\mathrm{pH}$ of the solution before $\mathrm{pH}_{\mathrm{o}}$ and after $48 \mathrm{~h} \mathrm{pH}_{\mathrm{f}}$ ). The intersection of obtained curve with $\mathrm{pH}_{\mathrm{o}}$ axis indicated the $\mathrm{pH}_{\mathrm{pzc}}$ value.

Figure 4 shows the plot between $\Delta \mathrm{pH}$, i.e., $\left(\mathrm{pH}_{\mathrm{o}}-\mathrm{pH}_{\mathrm{f}}\right)$ and $\mathrm{pH}_{\mathrm{o}}$ for $\mathrm{pH}_{\mathrm{pzc}}$, measurement for polyester foam. The point of zero charge is found to be 7.26. At a low $\mathrm{pH}\left(<\mathrm{pH}_{\mathrm{pzc}}\right.$, i.e., < 7.26) (Silva et al. 2004 and Hilal et al. 2013), the polyester foam surface should be net positive charge, and the AO67 dye molecules, with a sulfuric
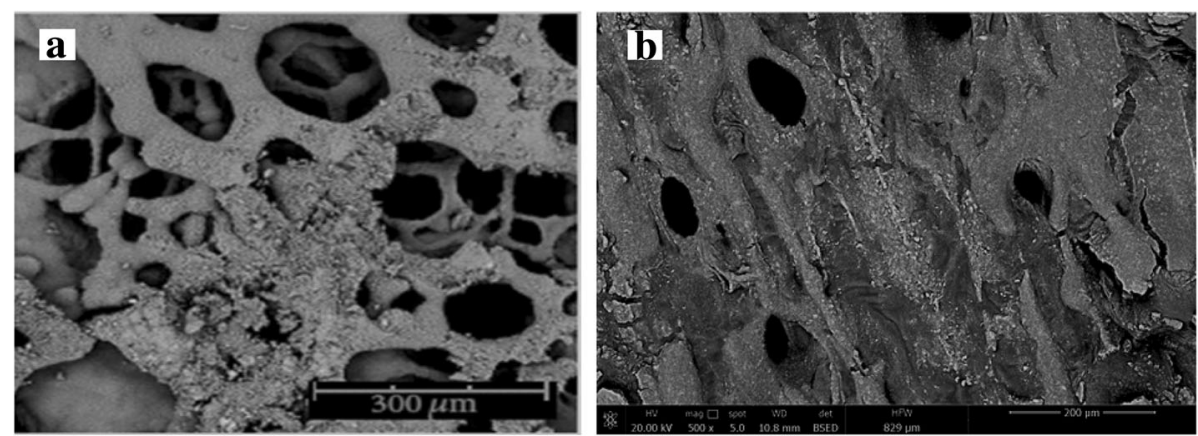

Fig. 2 SEM of RPSF without (a) and with (b) AO67 


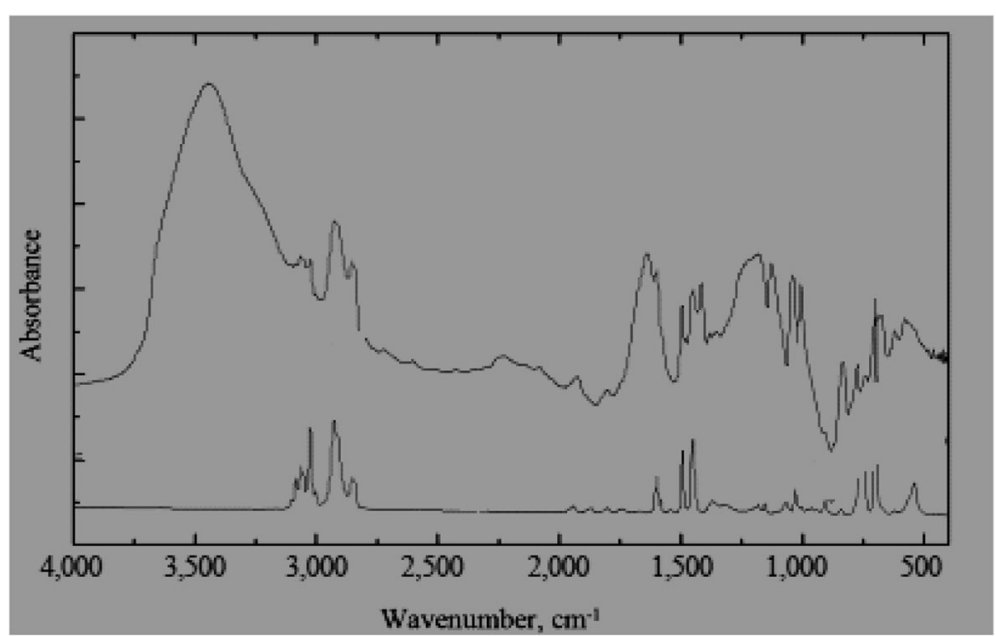

Fig. 3 FT-IR spectra of raw polystyrene foam and synthetic resin (RPSF)

group $\left(\mathrm{SO}_{3}\right)$, have a negative charge, attracting the polystyrene foam particles. Thus, the degradation reaction between the dye molecules and polystyrene foam could be achieved easily.

\section{Discussion}

\section{Adsorption studies}

\section{Effect of solution $\mathrm{pH}$}

Figure 5 shows the AO67 dye ions removal and adsorption capacity of RPSF wastes with variable solution $\mathrm{pH}$ values. From the figure, it is evident that the solution $\mathrm{pH}$ affects the adsorption process. The increase in solution $\mathrm{pH}$ from $\mathrm{pH} 1$ to 2.5 resulted in sharp a decrease in both percentage removal and adsorption capacity. The maximum adsorption of AO67 dye ions are obtained at $\mathrm{pH}$ 2.5. Therefore, $\mathrm{pH} 2.5$ was selected as optimum $\mathrm{pH}$ for AO67 ion adsorption onto RPSF wastes. Studying the effect of solution $\mathrm{pH}$ on the adsorption of Congo red by pine cone, they noticed that the adsorption was maximum at lower $\mathrm{pH}$, and this suggest lower $\mathrm{pH}$ solution results in an increase in the percentage of anionic dye removal because of the electrostatic attraction between the anionic dye and the positive surface charge of the adsorbent (Dawood and Sen 2012). At higher solution $\mathrm{pH}$, electrostatic repulsion is found between the negatively charged surface and dye molecules, this is due to the negative charge surface sites on the polystyrene foam wastes (RPSF) that were not favorable to the adsorption anionic dye due to electrostatic repulsion. Moreover, there was a competition between the hydroxide ions and the dye anions. The repulsion between anionic dye molecules and the excessive hydroxide ions resulted in a sharp decrease in adsorption, thus decreasing the adsorption capacity and percentage removal of anionic dyes (Salleh et al. 2011).

\section{Effect of resin of polystyrene foam wastes (RPSF) dosage}

Adsorbent dose is representing an important parameter due to its strong effect on the capacity of an adsorbent at given initial concentration of adsorbate. The effect of adsorbent dose on the removal percentage of the dye was conducted over a range of RPSF doses of 0.02 to 1.0 $\mathrm{g} / 40 \mathrm{~mL}$ at an initial concentration of $5-150 \mathrm{mg} / \mathrm{L}$ for minimum contact time $80 \mathrm{~min}$ at constant $\mathrm{pH} 2.5$, and the results are presented in Fig. 6 . From the figure, it is clearly observed that with increasing the adsorbent dose

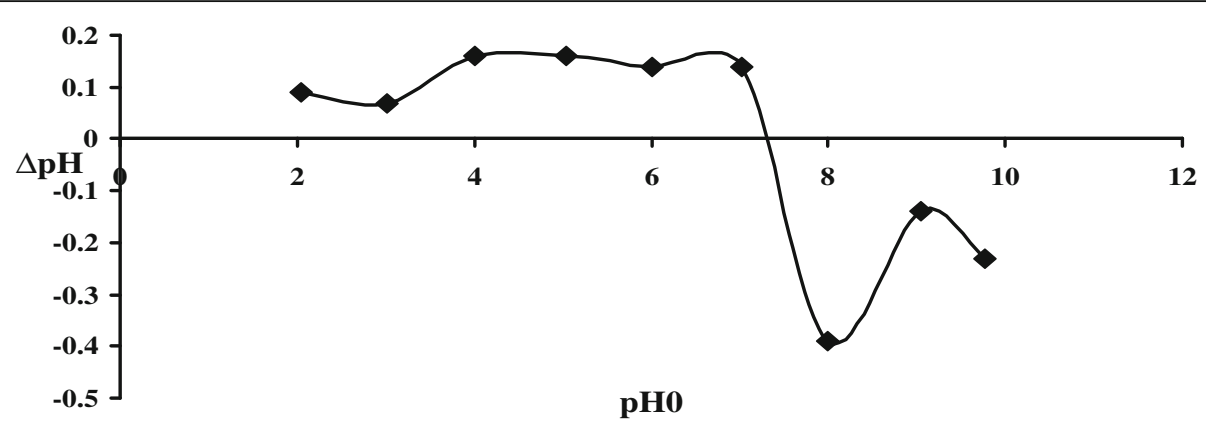

Fig. 4 Zero-point charge of RPSF 


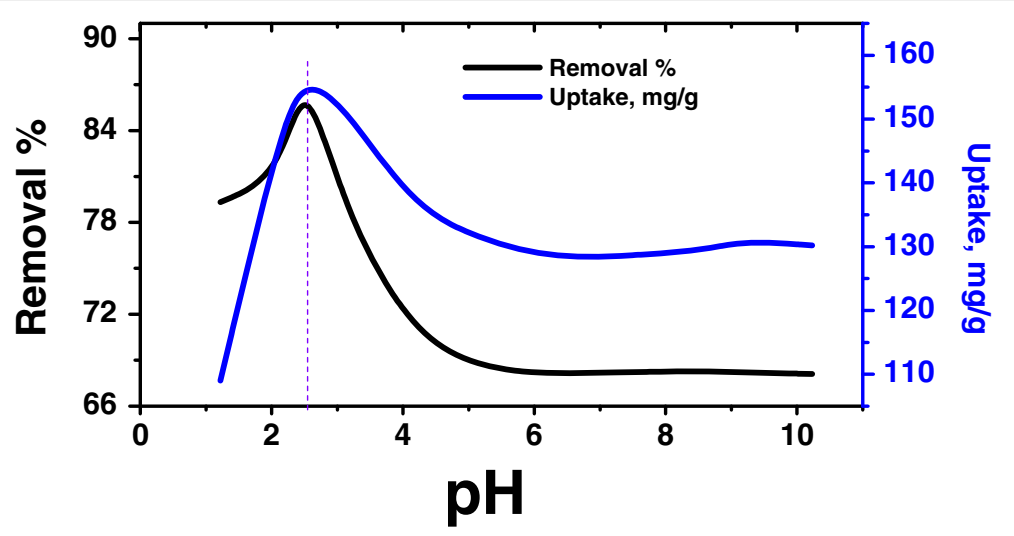

Fig. 5 Effect of solution pH on adsorption of AO67 onto RPSF

from 0.02 to $1.0 \mathrm{~g}$, dye removal efficiency was increased from 75.4 to 88.5 at $0.2 \mathrm{~g} / 40 \mathrm{~mL}$ and then decreased to $52.6 \%$ at $1.0 \mathrm{~g} / 40 \mathrm{~mL}$. This phenomenon was observed at the dye concentration studied. The increase in percentage removal with the adsorbent dose can be attributed to the increase of the available sorption surface and availability of more adsorption sites (Meena et al. 2012)

\section{Effect of initial dye concentration}

The relationship between initial dye concentrations, percentage removal, and the adsorption capacity has been investigated. The adsorption of dye was carried out at different initial dye concentration ranging from 5 to 150 $\mathrm{mg} / \mathrm{L}$ at $\mathrm{pH} 2.5 \pm 0.5$. The effect of different initial dye concentration on adsorption of dye onto resin polystyrene foam (RPSF) is presented in Fig. 7. The result indicated the percentage of dye removal decreases with an increase in the initial dye concentration, which may be due to the saturation of adsorption sites on the adsorbent surface. This can be explained by the fact that all adsorbents have a limited number of active sites and at a certain concentration the active sites become saturated. On the other hand, the increase in initial dye concentration will cause an increase in the capacity of the adsorbent and this may be due to the high driving force for mass transfer at a high initial dye concentration. The increase in the initial dye ions concentration also enhances the interaction between the dye ions in the aqueous phase and the adsorbent surface. This also resulted in higher uptake of dye for the given amount of adsorbent (Salleh et al. 2011). Thus, the effect of initial dye concentration depends on the immediate relation between the concentration of the dye and the available sites on an adsorbent surface. The initial concentration provides an important driving force to overcome all mass transfer resistance of dye ions between the aqueous and solid phases.

\section{Effect of contact time}

The relation between removal of the AO67 dye and reaction time was studied to see the rate of dye removal by resin of polystyrene foam (RPSF). The effects of

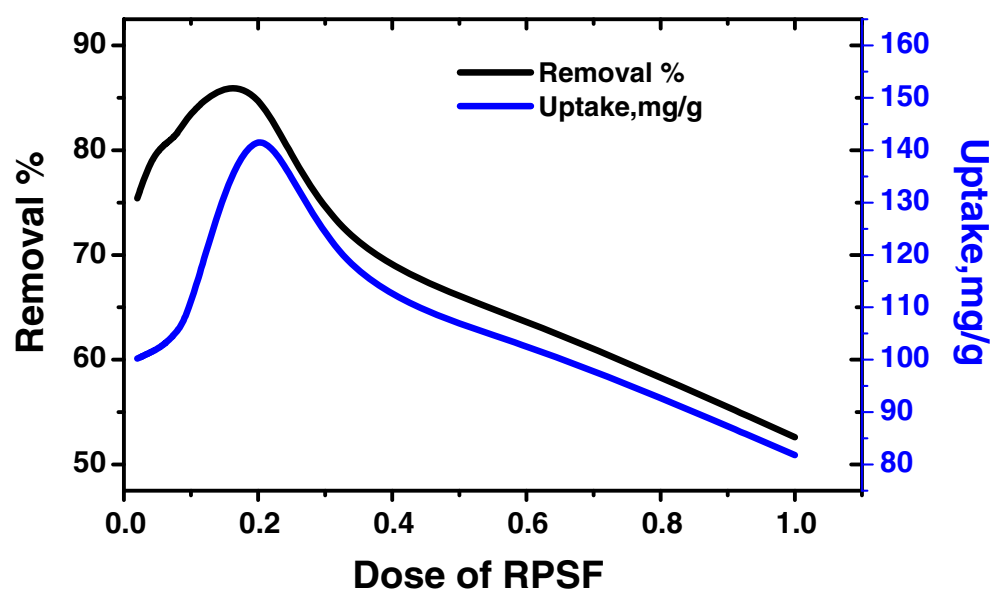

Fig. 6 Effect of adsorbent dosage of RPSF on adsorption of AO67 


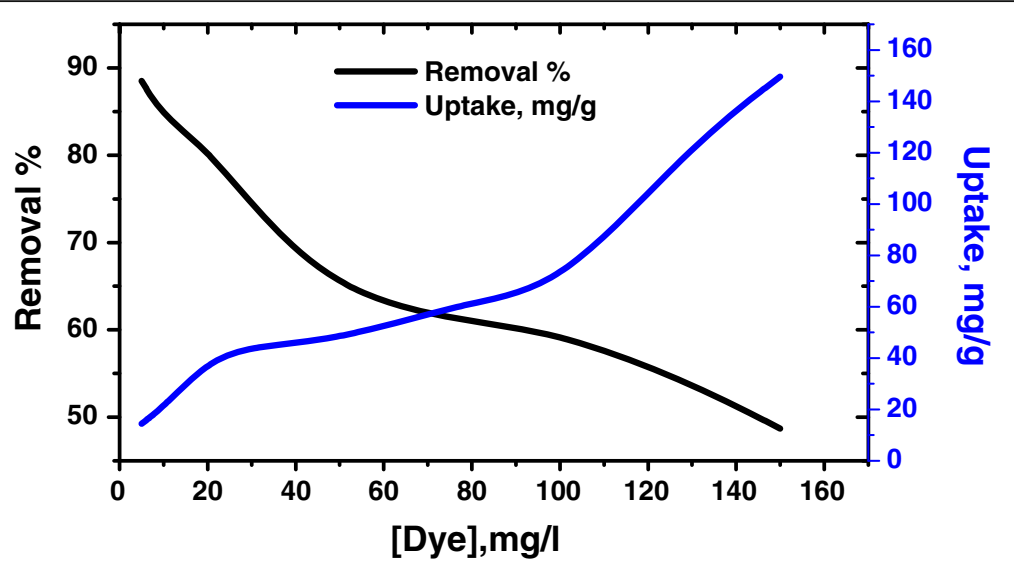

Fig. 7 Effect of initial dye concentration on adsorption of AO67

contact time on the removal of the dye by using fixed amount of $0.2 \mathrm{~g} / 40 \mathrm{~mL}$ of resin of polystyrene foam (RPSF) at different initial concentration (50, 100, and $150 \mathrm{mg} / \mathrm{L}$ ) are presented in Fig. 8. The results indicate that the rate of dye removal increased depending on the contact time. For the first $50 \mathrm{~min}$, the percentage removal of the dye by the adsorbent is rapid, and thereafter, it proceeds at a slower rate and finally attains saturation at different contact time for different initial concentration. The higher concentration solution of dyes employed, the longer equilibrium time was needed. The rate of removal of the dye is higher in the beginning due to the large surface area of the adsorbent available for the adsorption of dye ions. After a certain period, only a very low increase in the dye uptake was observed because there are few active sites on the surface of the adsorbent (Khaniabadi et al. 2017). From the contact time studied, it was revealed that $80 \mathrm{~min}$ of agitation time is enough to reach equilibrium when $100 \mathrm{mg} / \mathrm{L}$ of dyes concentration was employed. Therefore, equilibrium time of 80 min was selected for the adsorption of AO67 dye for further studies.

\section{Thermal effect}

Adsorption process of AO67 were also conducted at different temperatures $\left(25,40\right.$, and $\left.60^{\circ} \mathrm{C}\right)$ using $0.2 \mathrm{~g}$ of resin of polystyrene foam (RPSF) and $100 \mathrm{mg} / \mathrm{L}$ of AO67. The results indicated that the uptake capacity increased with increased solution temperature from 66.8 $\mathrm{mg} / \mathrm{g}$ at $25^{\circ} \mathrm{C}$ to $74.2 \mathrm{mg} / \mathrm{g}$ at $60^{\circ} \mathrm{C}$, which is attributed to enhanced diffusion of AO67 molecules towards the active sites of RPSF leading to higher adsorption capacity (Alkan et al. 2008).

\section{Summarize the effects of different variables on the dye removal in presence of RPSF}

The influence of the different process variables on the response factor (\% removal) is visualized in the 3D response surface plots (Fig. 9). In adsorption processes, both the adsorbent dose and solution $\mathrm{pH}$ play very

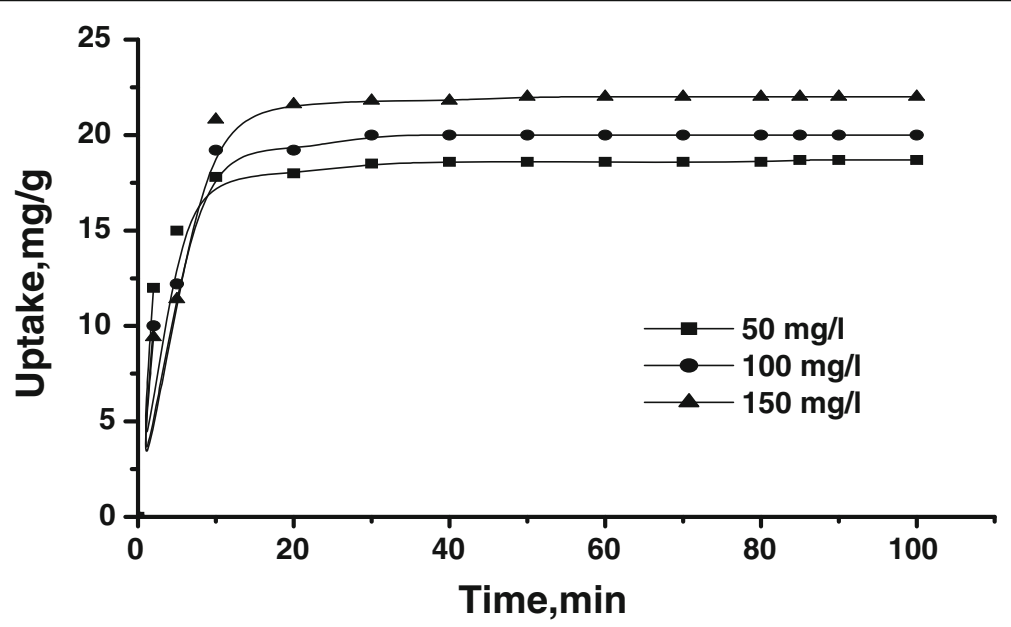

Fig. 8 Effect of contact time of AO67 onto resin polystyrene foam (RPSF) 

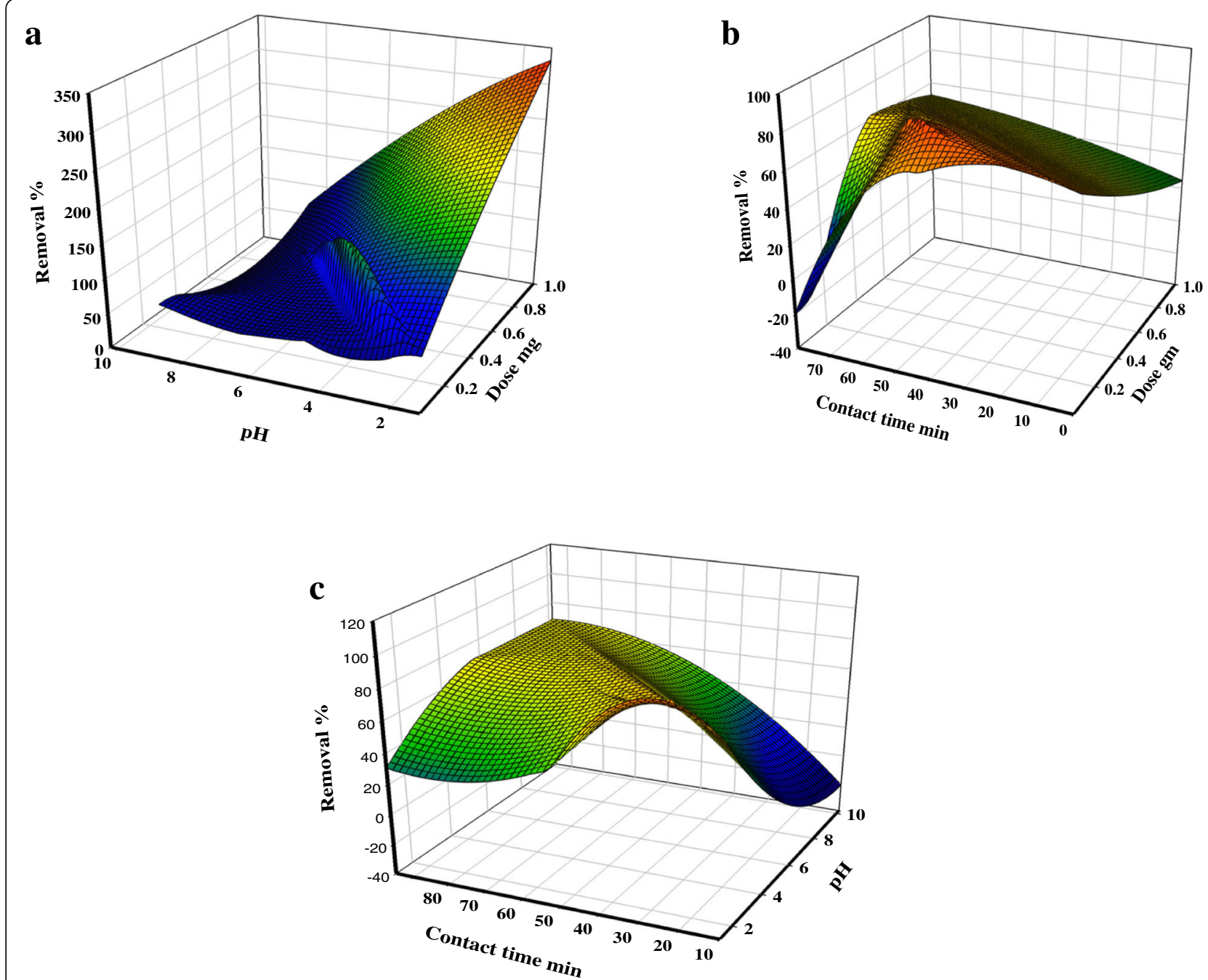

Fig. 9 3D graphs showing the effect of different variables on adsorption percent of AO67 on RPSF

important role. These variables are most effective in influencing the adsorption process. Figure 9a shows the three-dimensional response surfaces representing the combined effect of adsorbent dose and $\mathrm{pH}$ on adsorption of the dye at constant agitation rate $(200 \mathrm{rpm})$ and time $(80 \mathrm{~min})$. A decrease in the $\mathrm{pH}$ within the experimental range shows an enhancement in the adsorption rate of the dye. In acidic conditions, the surface of the adsorbent was positively charged due to the high concentration of $\mathrm{H}^{+}$, so the electrostatic attraction between the adsorbent and the anionic dye (AO67) was enhanced. In the alkaline condition, the adsorption of AO67 was reduced; this is probably due to the presence of $\mathrm{OH}^{-}$ions on the surface of adsorbents competing with anionic dye for adsorption sites. A maximum dye removal (88.5\%) was determined at constant agitation rate $(200 \mathrm{rpm})$ and time $(80 \mathrm{~min})$.

Figure $9 \mathrm{~b}$ shows the interactive influence of adsorbent dose and contact time on adsorption from the aqueous phase. It is evident that the dye removal percentage increases with increase in the contact time and the adsorbent dose in the experimental range as in cases discussed earlier. A maximum dye removal (91.1\%) was observed at constant $\mathrm{pH} 2.5$ and agitation rate $(200 \mathrm{rpm})$. The response surface plot for combined effect of the solution $\mathrm{pH}$ and the contact time (Fig. 9c) suggests that at lower $\mathrm{pH}$, the dye removal percentage by the RPSF increases with the increasing time. A maximum dye removal (89.5\%) was observed at constant adsorbent dose $(0.2 \mathrm{~g})$ and agitation rate (200 rpm).

\section{Dye adsorption kinetics models}

Adsorption kinetics is necessary for the design of adsorption system (Atef and Waleed 2009). In this present study, the following kinetic models were applied for the experimental data. 


\section{Pseudo-first-order kinetic model}

Pseudo-first-order kinetic model assumes that the rate of change of solute uptake with time is directly proportional to difference in saturation concentration and the amount of solid uptake with time (Lagergran et al. 1998). The rate constant of adsorption is expressed as a first-order rate expression given as:

$$
\operatorname{Ln}\left(q_{e}-q_{t}\right)=\ln q_{e}-\mathrm{k} t
$$

$q_{\mathrm{e}}$ is the concentration of AO67 adsorbed onto RPSF after equilibrium, $q_{\mathrm{t}}$ is the concentration of AO67 adsorbed onto RPSF adsorbed in time $t$, and $k_{1}\left(\mathrm{~min}^{-1}\right)$ is the pseudo-first-order rate constant.

The plot of $\log \left(q_{\mathrm{e}}-q_{\mathrm{t}}\right)$ versus $t$ should give a straight line with slope of $-k_{1} / 2.303$ and intercept $\log q$ e which allows calculation of adsorption rate constant $k_{1}$ and equilibrium adsorption capacity $q_{\mathrm{e}}$. The values of $k_{1}$ and $q_{\mathrm{e}}$ were calculated for the adsorption of AO67 dye on RPSF at three dye concentrations of 50,100, and $150 \mathrm{mg} /$ $\mathrm{L}$ with constant temperature $25^{\circ} \mathrm{C}$ and calculated values of $k_{1}$ and $q_{\mathrm{e}}$ at different temperatures 25,40 , and $60^{\circ} \mathrm{C}$ with constant dye concentration $100 \mathrm{mg} / \mathrm{L}$; the results are summarized in Table 1 . The pseudo-first-order kinetic model of Lagergran does not fit well with the experimental data over the whole range of initial concentrations studied.

\section{Pseudo-second-order kinetic model}

Pseudo-second-order rate equation (Karamipour et al. 2016) in the linear form is expressed as:

$$
t / q_{\mathrm{t}}=\left(t / q_{\mathrm{e}}\right)+\left(1 / k_{2} q_{\mathrm{e}}^{2}\right)
$$

where $k_{2}(\mathrm{~g} / \mathrm{mg} \mathrm{min})$ is the pseudo-second-order rate constant which can be calculated from the intercept of the straight line obtained from plotting $t / q_{t}$ vs. $t$, and $q_{e}$ is the equilibrium adsorption capacity $(\mathrm{mg} / \mathrm{g})$. Figure 10 shows the pseudo-second-order plot for the adsorption of AO67 dye by RPSF at various initial dye concentrations (temperature $25^{\circ} \mathrm{C}$ ), and Fig. 11 shows the pseudosecond-order plot for the adsorption of AO67 dye by RPSF at different temperatures 25,40 , and $60^{\circ} \mathrm{C}$ with constant dye concentration $100 \mathrm{mg} / \mathrm{L}$. A plot of $t / q_{\mathrm{t}}$

Table 1 Summary of the constants of different kinetic models for adsorption of AO67onto RPSF at different concentrations and

\begin{tabular}{|c|c|c|c|c|c|c|}
\hline \multirow[t]{2}{*}{ Constants } & \multicolumn{3}{|c|}{ Initial dye concentration (mg/L) } & \multicolumn{3}{|c|}{ Temperature $\left({ }^{\circ} \mathrm{C}\right)$} \\
\hline & 50 & 100 & 150 & 25 & 40 & 60 \\
\hline$q_{\mathrm{e}}$ exp., mg/g & 18.8 & 20.4 & 22.4 & 23.41 & 23.92 & 28.31 \\
\hline \multicolumn{7}{|c|}{ Pseudo-first-order kinetics } \\
\hline$K_{1}, \min ^{-1}$ & 0.0129 & 0.0297 & 0.0166 & 0.0288 & 0.0216 & 0.02 \\
\hline$q_{\mathrm{e}} \mathrm{cal}, \mathrm{mg} / \mathrm{g}$ & 5.04 & 18.59 & 18.59 & 18.22 & 12.78 & 13.092 \\
\hline$R^{2}$ & 0.9031 & 0.8642 & 0.9044 & 0.901 & 0.909 & 0.924 \\
\hline \multicolumn{7}{|c|}{ Pseudo-second-order kinetics } \\
\hline$k_{2}, \mathrm{~g} / \mathrm{mg} \min$ & 0.019 & 0.012 & $2.3 \times 10^{-3}$ & 0.0027 & 0.0065 & 0.0073 \\
\hline $\mathrm{H}$ & 7.22 & 6.18 & 1.75 & 1.88 & 4.1 & 6.24 \\
\hline$q_{\mathrm{e}} \mathrm{cal}, \mathrm{mg} / \mathrm{g}$ & 19.49 & 22.68 & 27.55 & 26.39 & 25.126 & 29.24 \\
\hline$R^{2}$ & 0.9985 & 0.9994 & 0.9809 & 0.9712 & 0.9938 & 0.998 \\
\hline \multicolumn{7}{|l|}{ Elovich Constant } \\
\hline A & $19.94 \times 10^{4}$ & 142.6 & 5.69 & 5.66 & 33.29 & 40.8 \\
\hline B & 0.882 & 0.412 & 0.2 & 0.1994 & 0.275 & 0.2278 \\
\hline$R^{2}$ & 0.8524 & 0.8686 & 0.832 & 0.8357 & 0.900 & 0.9083 \\
\hline \multicolumn{7}{|c|}{ Bingham's Constant } \\
\hline A & 0.0046 & 0.0052 & 0.0066 & 0.01 & 0.0071 & 0.0087 \\
\hline$K_{0}$ & 487.2 & 469.35 & 460.74 & 460.8 & 468.1 & 470 \\
\hline$R^{2}$ & 0.904 & 0.902 & 0.9182 & 0.917 & 0.9227 & 0.9274 \\
\hline \multicolumn{7}{|c|}{ Intra-particle diffusion model } \\
\hline$k_{\text {diff1 }}$ & 0.479 & 1.65 & 1.660 & 1.664 & 1.574 & 2.634 \\
\hline$R^{2}$ & 0.8955 & 0.8928 & 0.6531 & 0.6531 & 0.8256 & 0.9319 \\
\hline$k_{\text {diff2 }}$ & 0.4915 & 0.6128 & 1.27 & 1.27 & 1.35 & 1.46 \\
\hline$R^{2}$ & 0.9004 & 0.8903 & 0.8519 & 0.8519 & 0.9398 & 0.689 \\
\hline
\end{tabular}
different temperatures 


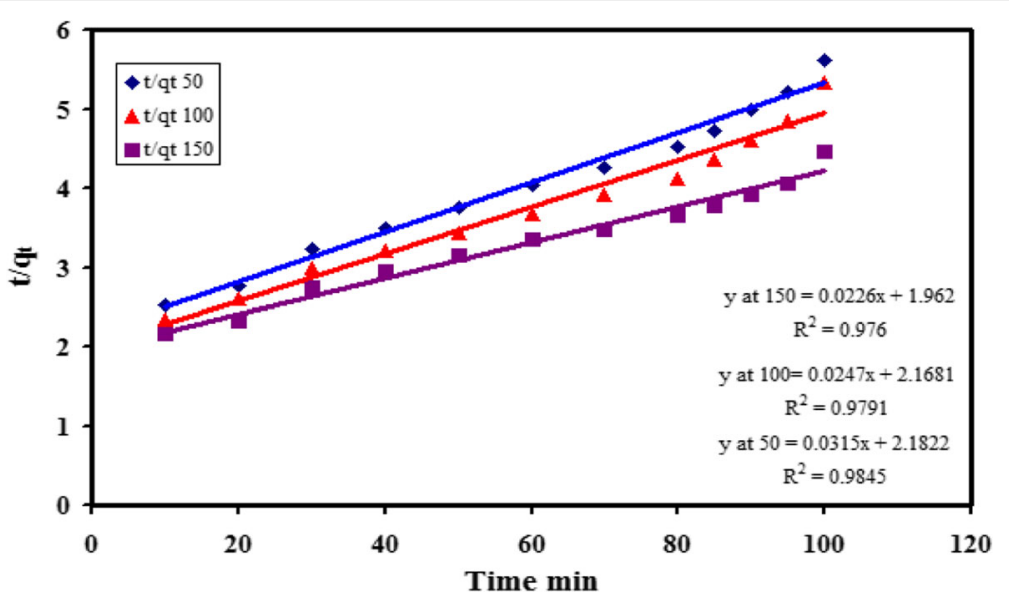

Fig. 10 Pseudo-second-order model plot at different concentration of adsorption AO67 onto RPSF $\left[\mathrm{pH}=2.5\right.$, temperature $25^{\circ} \mathrm{C}$, and adsorbent dose $0.2 \mathrm{~g}$ ]

against $t$ should give a linear relationship from which $k_{2}$ and $q_{\mathrm{e}}$ can be determined from the intercept and slope of the plot. The correlation coefficient values are greater than 0.99 (Table 1), and the data points give a linear straight line. It indicates that the adsorption of AO67dye by RPSF follow the pseudo-secondorder kinetic model. The second-order rate constants were used to calculate the initial sorption rate, $H$ ( $\mathrm{mg} / \mathrm{g} \mathrm{min})$, given by:

$$
H=k_{2} q_{\mathrm{e}}^{2}
$$

\section{Activation energy}

The rate constant $k_{2}$ at different temperatures listed in Table 2 was used to estimate the activation energy of the AO67 adsorption onto RPSF (Elizabeth et al. 2014).
Assume that the correlation among the rate constant $\left(k_{2}\right)$, temperature $(T)$, and activation energy $(E \mathrm{a})$ follows the Arrhenius equation, which induces the following expression:

$$
\ln k 2=\ln A-\frac{E a}{R T}
$$

where $R$ is the gas constant and the slope of plot of $\ln k_{2}$ versus $1 / T$ was used to evaluate $E$ a. The value of Ea was estimated to be $22.841 \mathrm{~kJ} / \mathrm{mol}$. The magnitude of activation energy gives an idea about the type of adsorption. The physisorption usually have energies in the range 5$40 \mathrm{~kJ} / \mathrm{mol}$, while higher activation energies of $40-800 \mathrm{~kJ} /$ mol suggest chemisorptions. The activation energy < $40 \mathrm{~kJ} / \mathrm{mol}$ for the dye indicates the diffusion controlled physisorption.

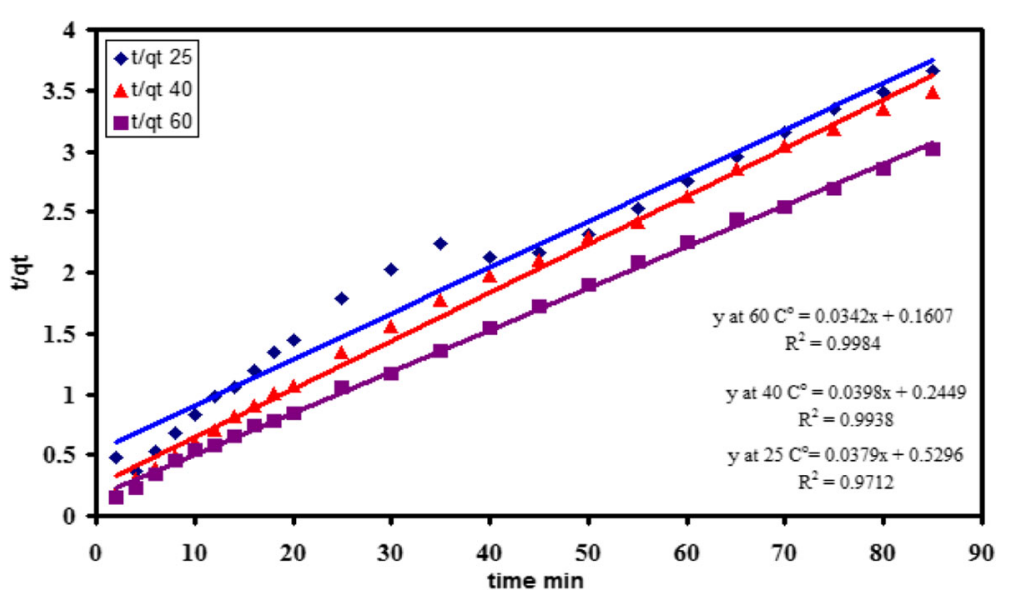

Fig. 11 Pseudo-second-order model plot at different temperature of adsorption AO67 onto RPSF $[p H=2.5$, concentration $100 \mathrm{mg} / \mathrm{L}$, and adsorbent dose $0.2 \mathrm{~g}]$ 
Table 2 Summary of the constants of different kinetic models for adsorption of AO67onto RPSF at different concentrations and different temperatures

\begin{tabular}{|c|c|c|c|c|c|c|c|c|c|c|c|}
\hline \multirow{2}{*}{$\begin{array}{l}\text { Temperature } \\
\left({ }^{\circ} \mathrm{C}\right)\end{array}$} & \multicolumn{3}{|c|}{ Langmuir isotherm } & \multicolumn{3}{|c|}{ Freundlich isotherm } & \multicolumn{3}{|c|}{ Temkin } & \multicolumn{2}{|c|}{ D-R isotherm } \\
\hline & $a_{m}, \mathrm{mg} / \mathrm{g}$ & $K_{\mathrm{L}}$ & $R^{2}$ & $\bar{n}$ & $K_{f}$ & $R^{2}$ & $\bar{a}$ & $B$ & $R^{2}$ & $q D-R$ & $R^{2}$ \\
\hline 25 & 82.64 & 0.0373 & 0.9791 & 1.64 & 5.27 & 0.9329 & 5.625 & 76.49 & 0.7211 & 65.26 & 0.5713 \\
\hline 40 & 113.6 & 0.034 & 0.9744 & 1.78 & 8.15 & 0.9536 & 5.016 & 68.47 & 0.7524 & 81.41 & 0.5311 \\
\hline 60 & 112.3 & 0.0449 & 0.9776 & 1.71 & 8.99 & 0.8653 & 6.224 & 50.83 & 0.6042 & 97.63 & 0.4258 \\
\hline
\end{tabular}

\section{The Elovich equation}

The validity of this equation suggests the reactions involving chemical adsorption of the adsorbent (Akazdam et al. 2017 and Kose and Kıvanç 2011). Equation (8) shows the mathematical form of the Elovich equation.

$$
\mathrm{d} q_{\mathrm{t}} / d_{\mathrm{t}}=\alpha \exp \cdot\left(-\beta q_{\mathrm{t}}\right)
$$

where $\alpha$ is the initial adsorption rate $(\mathrm{mol} / \mathrm{g} \mathrm{min})$ and $\beta$ is the desorption constant.

At time $t, \beta \alpha \ll 1$. To make simpler the Elvoich Eq. [18], it is assumed that by applying the boundary conditions, $q_{\mathrm{t}}=0$ at $t=0$, the simple form of equation is presented as Eq. (9):

$$
q_{t}=\beta \operatorname{Ln}(\alpha \beta)+\beta \operatorname{Ln}_{\mathrm{t}}
$$

The straight-line plot of $q_{\mathrm{t}}$ versus $\mathrm{Ln}_{\mathrm{t}}$ confirms the validity of the Elovich equation as the suitable kinetic model for the experimental data. The correlation coefficients of the plots of $q_{\mathrm{t}}$ versus $\mathrm{Ln}_{\mathrm{t}}$ for AO67 are 0.905, $0.91,0.923$, and 0.905 for 25,40 , and $60{ }^{\circ} \mathrm{C}$, respectively, and $0.911,0.935$, and 0.945 for 50,100 , and $150 \mathrm{mg} / \mathrm{L}$ concentration of dye, which indicates this model is not valid for this system. The results are summarized in Table 1 and show in (Fig. 12).

\section{Bangham's model}

It is generally expressed as (Akazdam et al. 2017):

$$
\log \left(\frac{c o}{c o-q t m}\right)=\log \left(\frac{k o m}{2.303 V}\right)+\alpha \log (t)
$$

where $C_{\mathrm{o}}$ is the initial concentration of the adsorbate in solution $(\mathrm{mg} / \mathrm{L}), \mathrm{V}$ is the volume of the solution $(\mathrm{l}), m$ is the weight of adsorbent used per liter of solution $(\mathrm{g} / \mathrm{L})$, $q_{\mathrm{t}}(\mathrm{mg} / \mathrm{g})$ the amount of adsorbate retained at time $t$, and $\alpha<1$ and $k_{\mathrm{o}}$ are constants determined from the plot of $\log \left[\mathrm{C}_{\mathrm{o}} / \mathrm{C}_{\mathrm{o}}-\mathrm{mq}_{\mathrm{t}}\right]$ versus $\log (\mathrm{t})$. Bangham's model constant can be computed from the slope and intercept of $\log \left[\mathrm{C}_{\mathrm{o}} / \mathrm{C}_{\mathrm{o}}-\mathrm{mq}_{\mathrm{t}}\right]$ versus $\log (\mathrm{t})$ at various effects (concentration and temperature) as shown in Figs. 12, 13, and 14. Table 2 lists the kinetic constants $\alpha$ and $k_{0}$ obtained from Bangham's equation. Thus, when temperature changed from 25 to $60{ }^{\circ} \mathrm{C}$, the value of $\alpha$ decreased from 0.010 to 0.008 and the value of $k_{\mathrm{o}}$ decreased from 14,454 to $598(\mathrm{~mL} / \mathrm{g} / \mathrm{L})$. The experimental data did not give a good correlation. In addition, it was found that the correlation coefficients for the Elovich model are higher than those obtained for Bangham's model (Table 2). This result confirmed that the pore diffusion is not the only rate-controlling step.

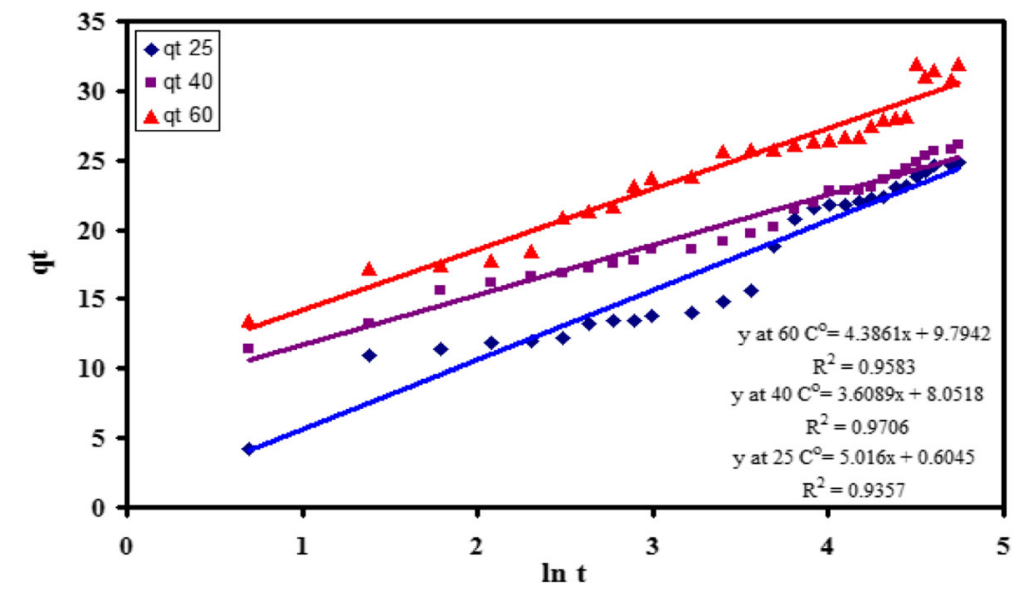

Fig. 12 Elovich equation model plot at different temperature of adsorption AO67 onto RPSF $[\mathrm{pH}=2.5$, concentration $100 \mathrm{mg} / \mathrm{L}$, and adsorbent dose $0.2 \mathrm{~g}$ ] 


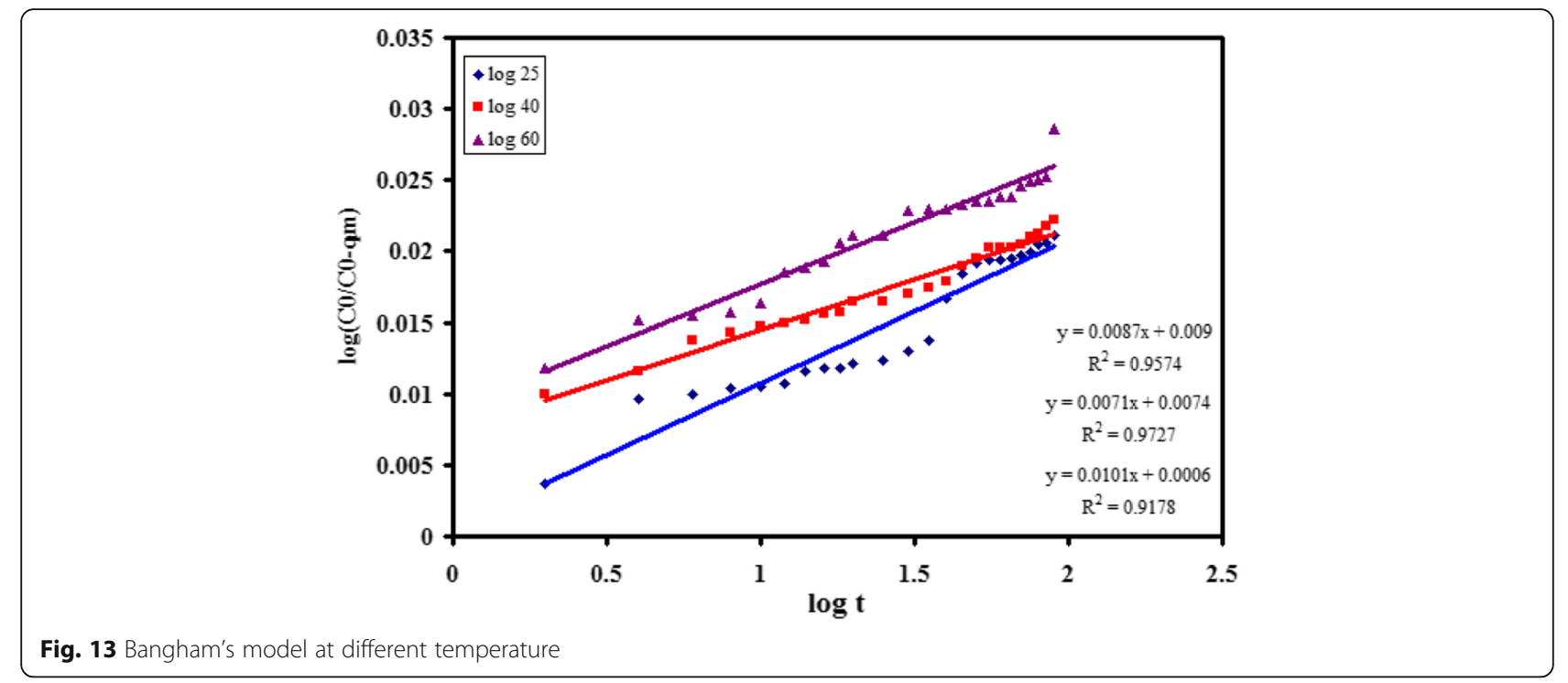

\section{Intra-particle diffusion model}

Adsorption is a multi-step process involving transport of the adsorbate (dye) molecules from the aqueous phase to the surface of the solid particles then followed by diffusion of the solute molecules into the pore interiors. If the experiment is a batch system with rapid stirring, there is a possibility that the transport of sorbate from solution into pores of the adsorbent is the rate-controlling step (Akazdam et al. 2017). Since the AO67 is probably transported from its aqueous solution to RPSF by intraparticle diffusion, so the intraparticle diffusion is another kinetic model developed by Weber and Morris should be used to study the rate-limiting step for AO67 adsorption onto RPSF. The intra-particle diffusion is commonly expressed by:

$$
q t=k \operatorname{dif} \sqrt{t}+C
$$

where $\mathrm{C}(\mathrm{mg} / \mathrm{g})$ is the intercept and $k_{d i f}\left(\mathrm{mg} / \mathrm{g} \mathrm{min}^{1 / 2}\right)$ is the intraparticle diffusion rate constant. The values of the amount of dye adsorbed qt were found to give two lines part with values of the square root of time $t^{1 / 2}$. The value of $C$ indicates the thickness of boundary layer, and with the larger value of $C$, the contribution of the surface sorption is greater in the rate-limiting step, (Fig. 13). The intraparticle diffusion rate constant $k_{\text {dif }}$ was in the range of $0.358-1.181 \mathrm{mg} / \mathrm{g} \mathrm{min}^{1 / 2}$, and it increases with an increase of temperature. For intraparticle diffusion plots, the first region in the figure is the external surface adsorption that can be attributed to the film diffusion. The second region is the gradual adsorption stage where intraparticle diffusion is the rate limiting. It confirms

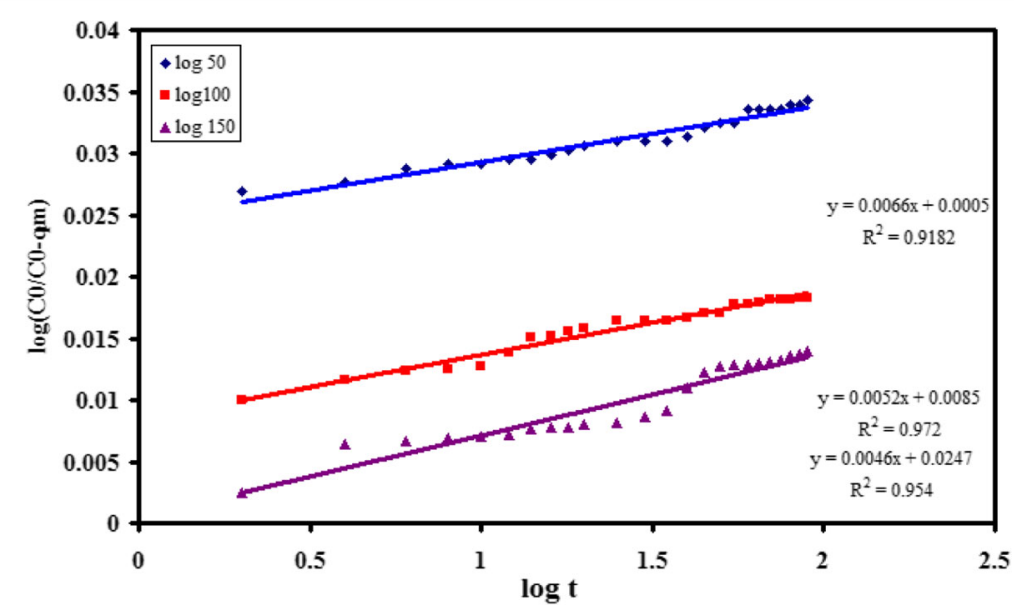

Fig. 14 Bangham's model at different concentration 
that intraparticle diffusion was not the only rate-limiting mechanism in the sorption process. The values of $k_{\text {dif- }}$ ${ }_{f l}$ and $k_{\text {diff } 2}$ as obtained from the slopes of the two straight lines are listed in Table 2. The values of the intraparticle diffusion rates $K_{\text {diff } 1}$ are smaller than the film diffusion rates $K_{\text {diff2 }}$. That gives prediction that the dye sorption process may be controlled by the intraparticle diffusion. The plot of constant of Weber and Morris equation depending on the concentration (Fig. 15) shows that the diffusion constant $(\mathrm{C})$ increases with increasing of the concentration in a linear fashion. This confirms that the limited step is the intra-granular distribution.

\section{Dye adsorption equilibrium isotherm models}

The adsorption isotherm is significant for the explanation of how the adsorbent will interact with the adsorbate and give an idea of adsorption capacity. The adsorption data collected in this study were fitted in to four well-known adsorption isotherm models, namely Langmuir, Freundlich, Dubinin-Radushkevich (D-R), and Temkin isotherm models.

\section{Langmuir adsorption isotherm}

The Langmuir isotherm model was chosen for estimation of the maximum adsorption capacity corresponding to complete monolayer coverage on the sorbent surface because this model is based on several basic assumptions (Barka et al. 2009)

(1) Adsorption is assumed to take place at specific homogenous sites with the adsorbent. (2) Once a dye molecule occupies a site, no further adsorption can take place at that site. (3) The adsorbent has a finite capacity for the adsorbate (at equilibrium). (4) All sites are identical and energetically equivalent.

Langmuir model (Langmuir 1916) is represented by the following equation.

$$
C_{\mathrm{e}} / q_{\mathrm{e}}=C_{\mathrm{e}} / q_{\mathrm{m}}+1 / \mathrm{K}_{\mathrm{L}} q_{\mathrm{m}} .
$$

where $q_{\mathrm{e}}$ is the amount of dye adsorbed at equilibrium $(\mathrm{mg} / \mathrm{g}), q_{\mathrm{m}}$ is the monolayer adsorption capacity $(\mathrm{mg} / \mathrm{g})$, $K_{\mathrm{L}}$ is the Langmuir constant related to energy of adsorption, and $C_{\mathrm{e}}$ is the equilibrium concentration $(\mathrm{mg} / \mathrm{L})$. Figure 16 shows a linear plot of $C_{\mathrm{e}} / q_{\mathrm{e}}$ against $C_{\mathrm{e}}$ for the removal of AO67 by RPSF. The Langmuir adsorption capacity varies from 82.64 to $113.60 \mathrm{mg} / \mathrm{g}$ for AO67 onto RPSF with an increase in temperature from 25 to $60^{\circ} \mathrm{C}$. This indicates that the adsorption is favored at high operating temperature. Similar results were reported for the removal of basic and acidic dyes by the low-cost adsorbent (Arivoli et al. 2008). The Langmuir isotherm fits quite well with the experimental data with very good correlation coefficient as shown in Table 2. $R_{\mathrm{L}}$ is the separation factor which is calculated by the following equation to confirm the favorability of the adsorption process (Filipkowska et al. 2002).

$$
R_{\mathrm{L}}=1 / 1+K_{\mathrm{L}} C_{\mathrm{o}}
$$

The values of $R_{\mathrm{L}}$ are found to be between 0 and 1 and confirm that the adsorption process is favorable.

\section{Freundlich adsorption isotherm}

The Freundlich isotherm is an important relationship describing the sorption of solute from a liquid to a solid surface (Fig. 17). Freundlich model (Freundlich 1906) is expressed as.

$$
\log q_{\mathrm{e}}=\log k_{f}+1 / n \log C_{\mathrm{e}}
$$

A plot of $\log q_{\mathrm{e}}$ versus $\log C_{\mathrm{e}}$ gives a linear line with a slope of $1 / n$ and intercept of $\log k_{f}$, and the results are given in Table 2 . From the experimental data, $k_{f}$ values

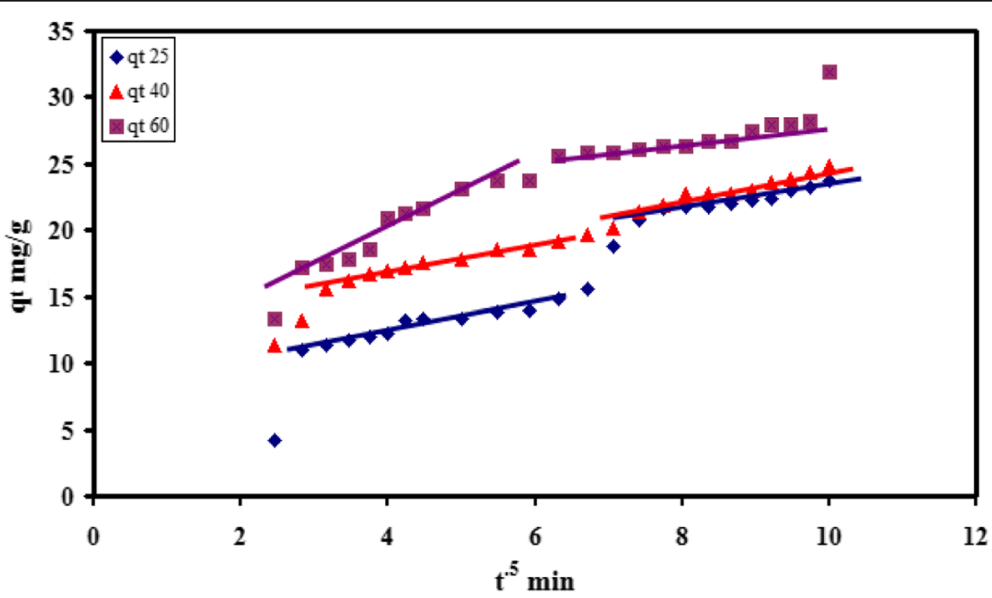

Fig. 15 Intraparticle diffusion at different temperature 


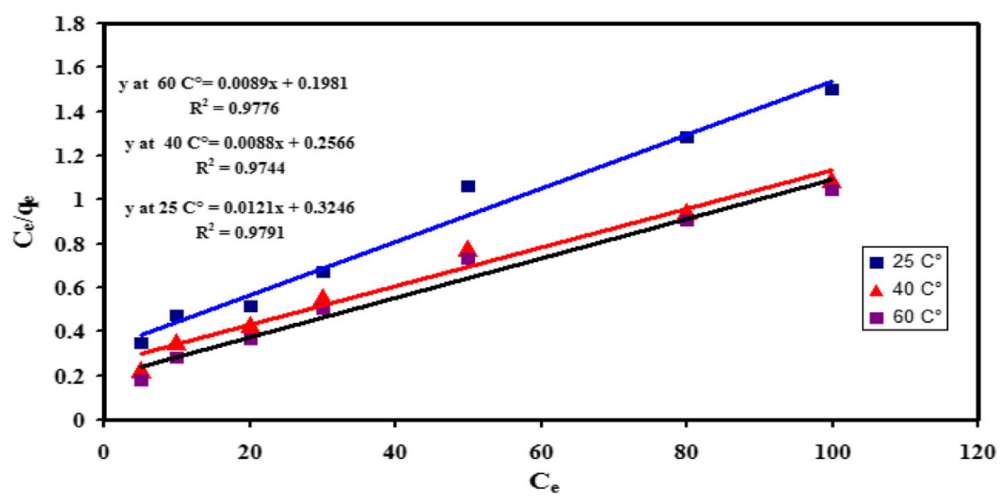

Fig. 16 Langmuir isotherm model plot of AO67 onto RPSF

increased with increasing temperature for AO67, implying that the adsorption process may be endothermic in nature. If $n<1$, then the bond energies increase with the surface density. If $n>1$, the bond energies decrease with the surface density. When $n=1$, all surface sites are equivalent. Alternatively, it has been show using mathematical calculation that $n$ values between 1 and 10 represent beneficial sorption. In the present study, the values of $n$ higher than unity represent a favorable adsorption condition. The correlation coefficient values are poor compared to the Langmuir isotherm model.

\section{Dubinin-Radushkevich (D-R) adsorption isotherm}

The D-R isotherm describes the adsorption on a single uniform pore (Fig. 18). Dubinin-Radushkevich isotherm (Subha and Namasivayam 2009) is generally expressed as follows:

$$
\begin{gathered}
\ln q e=I N q D-\beta \varepsilon^{2} \\
\varepsilon=R T \ln (1+1 / c e)
\end{gathered}
$$

$q_{\mathrm{D}}$ represents the maximum sorption capacity of the sorbent and $\beta$ is a constant related to the mean free energy of adsorption per mole of the adsorbate $\left(\mathrm{mol}^{2} /\right.$ $\left.\mathrm{J}^{2}\right) . R(\mathrm{~J} / \mathrm{mol} / \mathrm{K})$ is the gas constant and $T(\mathrm{~K})$ is the absolute temperature. The Polanyi adsorption theory postulates (Polanyi 1932) a fixed volume of sorption site close to sorbent surface and existence of sorption potential over these site. The sorption potential is related to an excess of sorption energy over the condensation energy and is independent of temperature. A plot of $\ln q_{\mathrm{e}}$ versus $\varepsilon^{2}$ gave a straight line, from which values of $q_{\mathrm{D}}$ and $\beta$ for AO67 onto RPSF were evaluated in Table 2. D-R isotherm is not able to describe the experimental data properly because of the poor linear correlation coefficient for the adsorption of the AO67 onto RPSF at different temperatures.

\section{Temkin isotherm model}

Temkin and Pyzhev (1940) considered the effects of some indirect adsorbate or adsorbate interactions on adsorption isotherms and suggested that because of these interactions the heat of adsorption of all the molecules in the layer would decrease linearly with coverage (Fig. 19). The Temkin isotherm has commonly been applied in the following form:

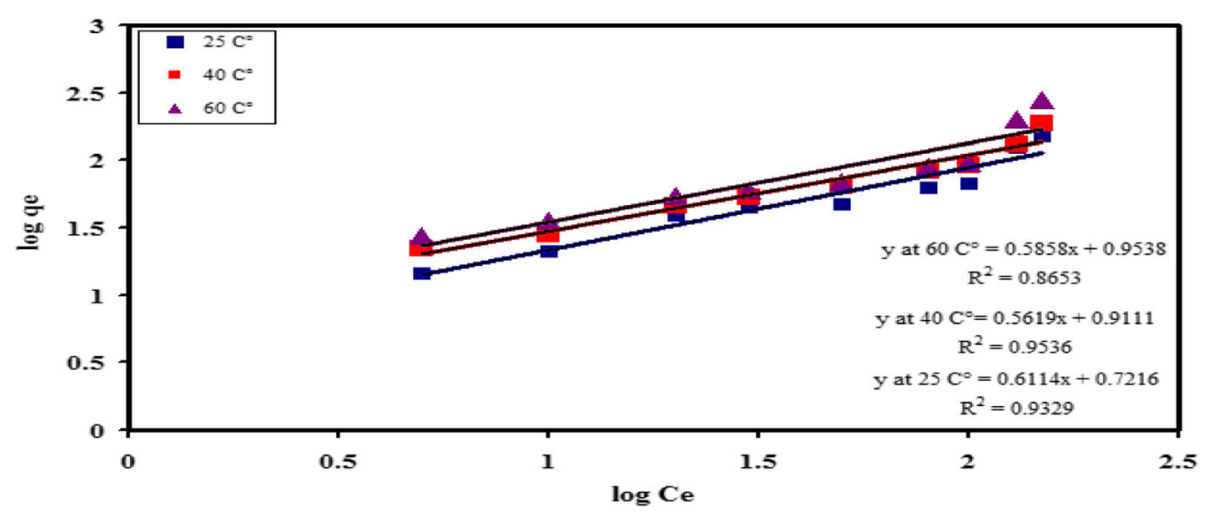

Fig. 17 Freundlich isotherm model plot 


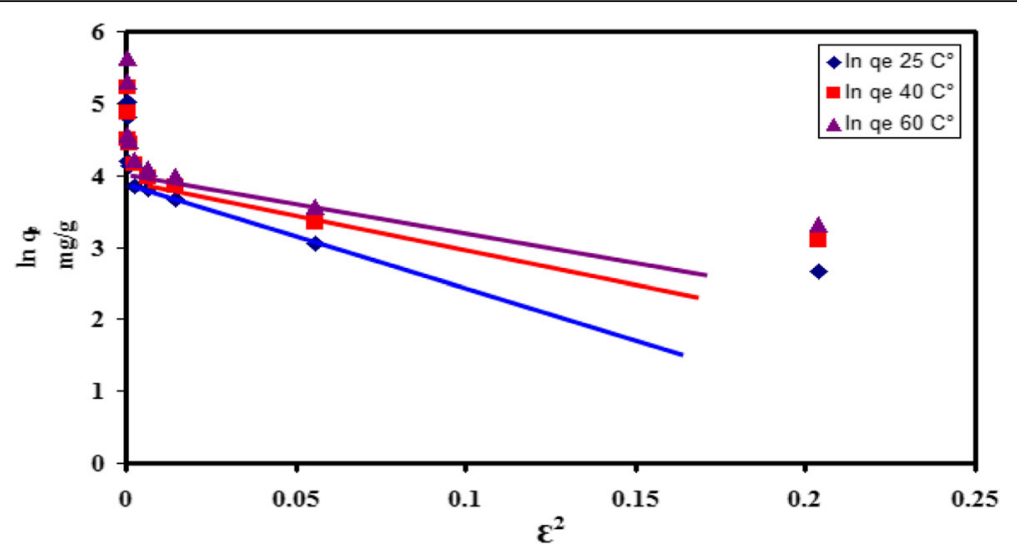

Fig. 18 Dubinin-Radushkevich isotherm model plot

$$
q_{\mathrm{e}}=(\mathrm{RT} / \mathrm{B}) \ln A+(\mathrm{RT} / \mathrm{B}) \ln C_{\mathrm{e}}
$$

The Temkin constants $\mathrm{A}$ and $\mathrm{B}$ are calculated from the slope and the intercept of $q_{\mathrm{e}}$ versus $\ln C_{\mathrm{e}}$. The linear isotherm constants and coefficients of determination are presented in Table 2. Examination of the data shows that the Temkin isotherm is not applicable to the AO67 adsorption onto RPSF adsorbent judged by a low correlation coefficient $\left(R^{2}\right)$.

\section{Thermodynamic studies}

Thermodynamic parameters such as enthalpy change $\Delta H^{\circ}$, free energy change $\Delta G^{\circ}$, and entropy change $\Delta S^{o}$ can be estimated using equilibrium constants changing with temperature. The free energy change of the sorption reaction is given by equation van't Hoff equation (Abramian and El-Rassy 2009 and Ahmed and Hameed 2018)

$$
\ln K_{\mathrm{C}}=\frac{\Delta \mathrm{S}}{\mathrm{R}}-\frac{\Delta \mathrm{H}}{\mathrm{RT}}
$$

$$
\Delta G=\Delta S-T \Delta H
$$

where $\Delta G^{o}$ is the standard free energy change, Joule; $R$ is universal gas constant, $8.314 \mathrm{~J} \mathrm{~mol}^{-1} \mathrm{~K}^{-1}$; and $T$ is absolute temperature. $K_{\mathrm{C}}$ is called adsorption affinity which is defined as the ratio of dye uptake and dye concentration in the aqueous solution at equilibrium $\left(q_{\mathrm{e}}\right)$ $\left.C_{\mathrm{e}}\right) \cdot q_{\mathrm{e}}$ is the amount of dye adsorbed per unit mass of adsorbent at equilibrium, and $C_{\mathrm{e}}$ is the equilibrium concentration of the adsorbate in the solution. The thermodynamic characteristics for the adsorption process were evaluated through computation of Gibb's free energy $\left(\Delta G^{\circ}\right)$, enthalpy of adsorption $\left(\Delta H^{\circ}\right)$, and entropy of adsorption $\left(\Delta S^{\circ}\right)$ from the experiments carried at three different temperatures. The free energy changes for AO67dye adsorption onto RPSF were determined by using the equilibrium concentration values obtained from Langmuir isotherm model. $\Delta G^{o}$ and $\Delta S^{o}$ values of AO67 dye at different temperatures $(298,313,333 \mathrm{~K})$ were given in Table 3.The negative values of $\Delta G^{o}$ confirmed the spontaneous nature of the process at all temperatures. The $\Delta G^{o}$ values obtained were in the range of

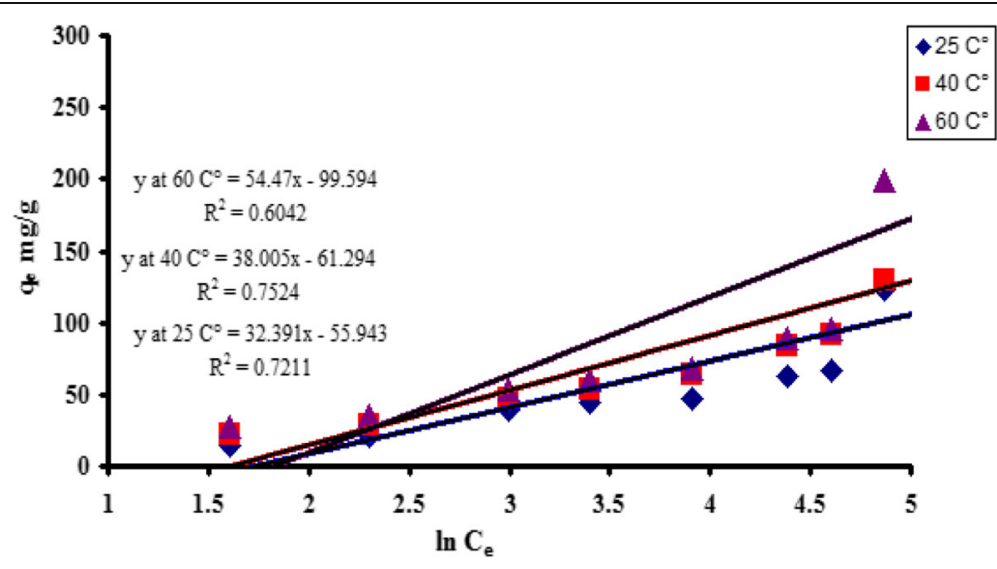

Fig. 19 Temkin isotherm model plot at different temperatures 
Table 3 Summary of Thermodynamic Parameter of AO67 onto RPSF

\begin{tabular}{llcc}
\hline Temperature $(\mathrm{K})$ & $\Delta \mathrm{G}(\mathrm{kJ} / \mathrm{mol})$ & $\Delta \mathrm{H}(\mathrm{kJ} / \mathrm{mol})$ & $\Delta \mathrm{S}(\mathrm{J} / \mathrm{K} \mathrm{mol})$ \\
\hline 298 & -1.18336 & & \\
313 & -1.95397 & 14.132 & 0.0514 \\
333 & -2.9821 & & \\
\hline
\end{tabular}

-1.183 to $-2.982 \mathrm{~kJ} / \mathrm{mol}$, which indicate that the adsorption process was a physical adsorption. The values of $\Delta G^{\circ}$ became more negative as temperature increases which suggests that increase in temperature was favorable for AO67 adsorption on RPSF.

From the plot, the standard enthalpy change, $\Delta H^{o}$, and the standard entropy change, $\Delta S^{\circ}$, were determined using the slope and intercept of the plot between $\ln K_{\mathrm{C}}$ versus $1 / T$. The values of $\Delta H^{o}$ and $\Delta S^{o}$ were $14.132 \mathrm{~kJ} /$ mol and $0.0514 \mathrm{~kJ} / \mathrm{mol}, \mathrm{K}$, respectively. The positive values of $\Delta H^{o}$ indicate that the adsorption of AO67 on RPSF was endothermic and irreversible nature of the process (Khosla et al. 2013). Positive value of $\Delta S^{o}$ indicates the AO67 molecules were suggested to have favorable randomness factor though its value is small. This suggests that despite the small particle size of adsorbent the reaction is energetically favorable. The thermodynamic parameters were calculated and are given in Table 3.

\section{Removal of RB222, RY 145, and AR37 from simulated wastewater by RPSF}

Under optimum conditions which were attained in this study for removal of AO67 onto RPSF from aqueous solution, removal of reactive Blue 222 (RB222), reactive Yellow 145 (RY145), and Acid Red 37 (AR37) was studied from the simulated wastewaters onto RPSF. The low and the high amount of adsorbent, contact time, the capacity of adsorbents, and removal percentages were considered in the simulated wastewaters. Figures 20 and 21 represent the effect of contact time on removal percentage and adsorbent capacity. The figures show the removal of different dyes (AO67, RB222, RY145, and AR37) from wastewaters may be carried out by using RPSF under optimum conditions, the effect of adsorbent more affective for dye AR37 than dyes AO67, RB222, and RY145.

\section{Conclusion}

The ability of RPSF in removing the anionic dye AO67 dye from aqueous solution has been investigated. RPSF could almost remove over $88.5 \%$ of AO67 within $80 \mathrm{~min}$ of contact time; adsorbent dose $0.2 \mathrm{~g} / \mathrm{L}$ and the solution $\mathrm{pH}=2.5 \pm 0.5$ have important bearing on the extent of this process. This indicates that the $\mathrm{pH}$ is more important in the controlling of adsorption rather than the nature of the surface sites. This work confirms that the RPSF could be used for the removal of dyes from aqueous solutions. The equilibrium time is independent of the concentration, and the amount adsorbed at equilibrium increases with concentration. This is because the diffusion of dye molecules from the solution to the surface of the adsorbent is accelerated by increasing the dye concentration. The adsorbed amount increases with increasing temperature. Results indicate that the adsorption isotherm data were fitted in good agreement with the Langmuir isotherm model by comparing the values of the linear correlation coefficient $R^{2}$. The adsorption process followed the pseudo-second-order kinetics, and the calculation of activation energy indicates the adsorption process in physical nature. The positive values of $\Delta H^{o}$ indicate that the adsorption process of AO67 on RPSF was endothermic and irreversible in nature. Positive value of $\Delta S^{o}$ indicates the AO67 molecules were suggesting favorable randomness factor though its value is small. This suggests that despite

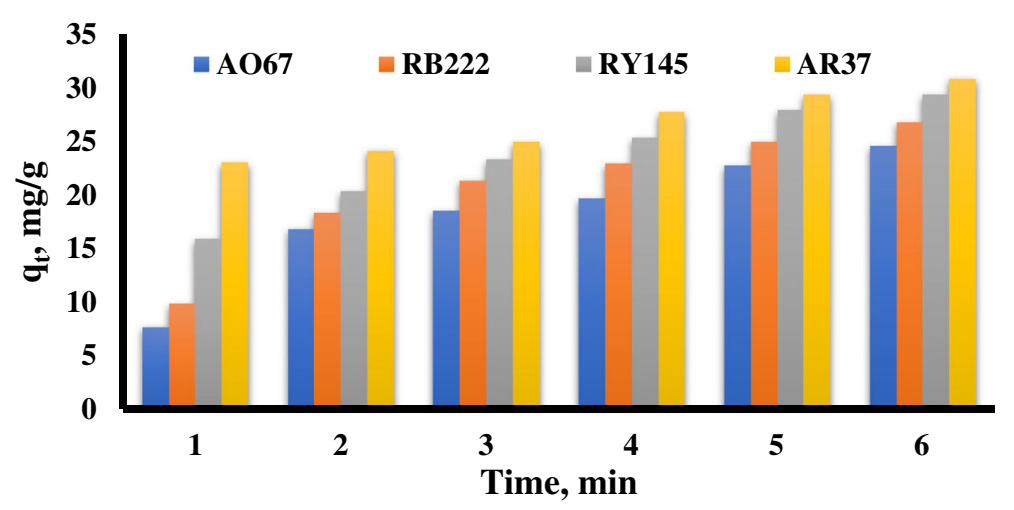

Fig. 20 Effect of contact time on removal \% of RB 222, RY 145, AO67, and AR37 by RPSF at optimum condition 


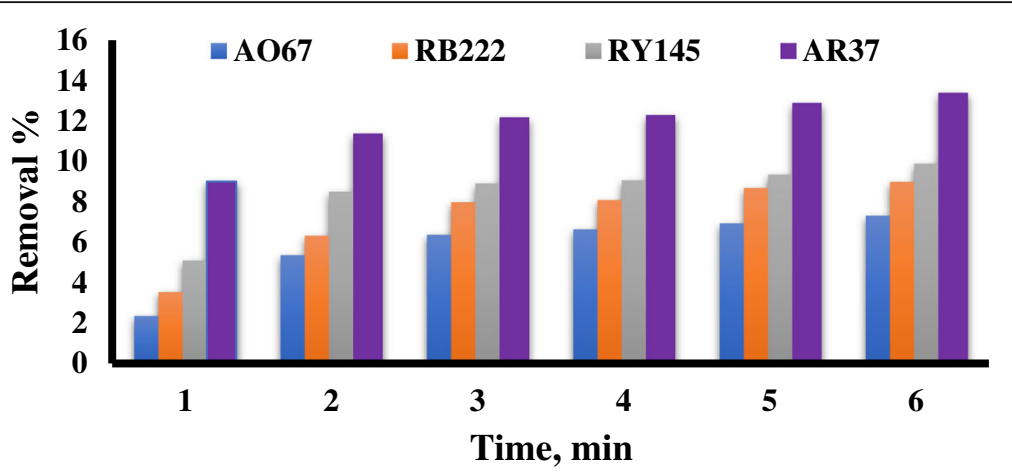

Fig. 21 Effect of contact time on adsorption capacity of RPSF to RB 222, RY 145, AO67, and AR37 at optimum condition

the small particle size of adsorbent the reaction is energetically favorable. The removal of different dyes (AO67, RB222, RY145, and AR37) from wastewaters may be carried out by using RPSF under optimum conditions, the effect of adsorbent more affective for dye AR37 than dyes AO67, RB222, and RY145).

\section{Abbreviations}

AO67: Acid Orange 67; AR37: Acid Red 37; C.I.: Color Index; FTIR: Fouriertransform infrared spectroscopy; N: Normal; pHpzc: Point zero charge; RB222: Reactive Blue 222; rpm: Revolutions per minute; RPSF: Resin polystyrene foam; RY145: Reactive Yellow 145; SEM: Scanning electron microscopy; TEM: Transmission Electron Microscope; UV: Ultraviolet; XRD: Xray diffraction

\section{Acknowledgements}

The authors acknowledge with thanks for the technical support.

\section{Funding}

All authors equally shared in financing the cost of the research paper.

\section{Availability of data and materials}

All data generated or analyzed during this study are included in this published article.

\section{Authors' contributions}

All authors contribute in the work and in writing the manuscript. All authors read and approved the final manuscript.

\section{Ethics approval and consent to participate}

The manuscript does not contain studies involving human participants, human data, or human tissue.

\section{Consent for publication \\ Not applicable.}

\section{Competing interests}

The authors declare that they have no competing interests.

\section{Publisher's Note}

Springer Nature remains neutral with regard to jurisdictional claims in published maps and institutional affiliations.

Received: 22 January 2019 Accepted: 12 March 2019 Published online: 04 April 2019

\section{References}

Abramian L, El-Rassy H (2009) Adsorption kinetics and thermodynamics of azodye Orange II onto highly porous titania aerogel. J Chem Eng 150:403-410.
Adak A, Bandyopadhyay M, Pal A (2005) Removal of crystal violet dye from wastewater by surfactant-modified alumina. J Sep Purif Technol 44:139-144.

Ahmed MJ, Hameed BH (2018) Adsorption behavior of salicylic acid on biochar as derived from the thermal pyrolysis of barley straws. J Cleaner Product 195: 1162-1169.

Akazdam S, Chafi M, Yassine W, Gourich B (2017) Removal of Acid Orange 7 dye from aqueous solution using the exchange resin Amberlite FPA-98 as an efficient adsorbent: kinetics, isotherms, and thermodynamics study. J Mat Environ Sci 8:2993-3012.

Alkan M, Dogan M, Turhan Y, Demirbas O, Turan P (2008) Adsorption kinetics and mechanism of maxilon blue $5 \mathrm{G}$ dye on sepiolite from aqueous solutions. J Chem Eng 139:213-223.

Arivoli S, Sundaravadivelu M, llango KP (2008) Removal of basic and acidic dyes from aqueous solution by adsorption on a low cost activated carbon: kinetic and thermodynamic study. Ind J Chem Tech 15:130-139.

Atef AS, Waleed M (2009) Equilibrium kinetic and thermodynamic studies on the adsorption of phenol onto activated phosphate rock. Int J Phy Sci 4:172-181.

Bajpai SK, Sorptive JA (2010) Removal of crystal violet from aqueous solution using spent tea leaves: part I optimization of sorption conditions and Kinetic Studies. J Act Chim Slov 36:57-751.

Barka N, Assabbane A, Nounah A, Laanab L, Ichou YA (2009) Removal of textile dyes from aqueous solutions by natural phosphate as a new adsorbent. J Desalin 235:264-275.

Bekri-Abbes I, Bayoudh S, Baklouti M (2008) The removal of hardness of water using sulfonated waste plastic. J Desalination 222:81-86.

Bhattacharyya KG, Sharma A (2005) Kinetics and thermodynamics of methylene blue adsorption on Neem (Azadirachta indica) leaf powder. J Dyes Pigments 65:9-51.

Dawood S, Sen TK (2012) Removal of anionic dye from aqueous solution by raw pine. J Water Res 6:46-19.

Elizabeth RG, Ricardo LM, Marcos ML, Isaías HP, Maria JV, Ana MM (2014) Adsorption of Azo-Dye Orange II from aqueous solutions using a metalorganic framework material: iron- benzenetricarboxylate. J Mater 7:80378057.

Filipkowska U, Klimiuk E, Grabowski S, Siedlecka E (2002) Adsorption of reactive dyes by modified chitin from aqueous solutions. J Polish Environ Stud 11: 315-323.

Freundlich HMF (1906) Over the adsorption in solution. J Phys Chem 57:385-470. Gupta V (2009) Application of low-cost adsorbents for dye removal —a review. J Environ Manage 90:2313-2342.

Hameed B, Ahmad A (2009) Batch adsorption of methylene blue from aqueous solution by garlic peel, an agricultural waste biomass. J Hazard Mat 164:870875.

Hilal NM, Emam AA, El-Bayaa AA, Badawy NA, Zidan AE (2013) Adsorption of barium and Iron ions from aqueous solutions by the activated carbon produced from Mazot Ash. J Life Sci 75:83.

Hu Z (2007) Genetic reconstruction of a functional transcriptional regulatory network. J Nat Genet 39:683-687.

Karamipour A, Rasouli N, Movahedi M, Salavati HA (2016) Kinetic study on adsorption of Congo red from aqueous solution by $\mathrm{ZnOZnFe}_{2} \mathrm{O}_{4}$-polypyrrole magnetic nanocomposite. J Phys Chem Res 4:291-301.

Khaniabadi YO, Mohammadi MJ, Shegerd M, Sadeghi S, Saeedi S, Basiri H (2017) Removal of Congo red dye from aqueous solutions by a low-cost adsorbent: 
activated carbon prepared from aloe vera leaves shell. J Environ Health Eng Manage 29:35.

Khosla E, Kaur S, Dave PN (2013) Mechanistic study of adsorption of Acid Orange-7 over aluminum oxide nanoparticles. J Hindawi Publishing Corp Eng 8:Article ID 593534.

Kose TE, KIvanç B (2011) Adsorption of phosphate from aqueous solutions using calcined waste eggshell. J Chem Eng 178:34-39.

Lagergran S, Sven K, Hand V (1998) Thermodynamic and dynamic of chromium biosorption by pectic and ligno cellulocic biowastes. J Water Resour Prot 24: $1-39$.

Langmuir I (1916) The constitution and fundamental properties of solids and liquids. J Am Chem Soc 38:2221-2295.

Meena S, Yadav S, Ashok S (2012) Adsorptive removal of methylene blue dye from an aqueous solution using water hyacinth root powder as a low-cost adsorbent. Inte J Chem Sciand Appl 3:338-345.

Mohanty BK (2006) The Tof1p-Csm3p protein complex counteracts the Rrm3p helicase to control replication termination of Saccharomyces cerevisiae. J Proc Nat Acad Sci U S A 103:897-902.

Polanyi M (1932) Section III.--theories of the adsorption of gases. A general survey and some additional remarks. Introductory paper to section III. J Transact Faraday Soc 28:316-333.

Prapat P, Wipasinun T, Suparat N (2011) Removal of hardness from groundwater by synthetic resin from waste plastics. Int J Envi Sci and Devel 2:479-483.

Salleh MA, Mahmoud DK, Abdul Karim WA, Idris A (2011) Cationic and anionic dye adsorption by agricultural solid wastes: a comprehensive review. J Desalination 280:1-13.

Sears GW (1956) Determination of specific surface area of colloidal silica by titration with sodium hydroxide. J Analytical Chem 28:1981-1983.

Silva JP, Sousa S, Rodrigues J, Antunes H, Porter JJ, Gonçalves I, Dias SF (2004) Adsorption of acid orange 7 dyes in aqueous solutions by spent brewery grains. J Sep Purif Technol 40:309-315.

Subha R, Namasivayam C (2009) Zinc chloride activated coir pith carbon as lowcost adsorbent for removal of 2, 4-dichlorophenol: equilibrium and kinetic studies. Ind J Chem Tech 16:471-479.

Temkin Ml, Pyzhev V (1940) Kinetics of ammoniasynthesis on promoted iron catalysis. Acta Phsicochim USSR 12:217-222.

\section{Submit your manuscript to a SpringerOpen ${ }^{\circ}$ journal and benefit from:}

- Convenient online submission

- Rigorous peer review

- Open access: articles freely available online

High visibility within the field

- Retaining the copyright to your article

Submit your next manuscript at $\boldsymbol{\nabla}$ springeropen.com 